\title{
Effective Virtual Interventions to Enhance Psychological Capital: A mixed-methods systematic review
}

Mar 30, 2021

Joy Xu, ${ }^{1}$ Aljeena Rahat Qureshi, ${ }^{1}$ Yar Mohamed Al Dabagh, ${ }^{1}$ Cynthia Lai Kin, ${ }^{2}$ Rida Khan ${ }^{1}$

${ }^{1}$ McMaster University, Hamilton, ON, Canada

${ }^{2}$ University of Waterloo, Waterloo, ON, Canada

Contact Info: joyxu@gmail.com

\begin{abstract}
Background

Developed from positive psychology, Psychological Capital (PsyCap) entails a collection of intrinsic traits which may be optimized for productive and sustainable outcomes in life. This systematic review explores potential virtual implementation of PsyCap interventions, especially given the digital transition amidst the COVID-19 pandemic and its potential usage in the future. Methods

Utilizing a mixed-methods systematic review, this convergent integrated synthesis involves database searches conducted in APA PsychINFO, Web of Science and PubMed with literature published between 1995 and 2020. This systematic review follows the Preferred Reporting Items for Systematic Review and Meta-Analyses (PRISMA) guidelines with a registered PROSPERO protocol. With diverse study designs and accompanying grey literature, heterogeneity precluded statistical analysis for qualitative presentation of included studies. Study screening, extraction, and quality appraisal (using the Mixed Methods Appraisal Tool) were performed by two authors independently and reconciled. Disagreements were resolved by a third author.
\end{abstract}

\section{Results}

Present literature has determined effective increase of PsyCap with the PCI Intervention Model. Strengths-based interventions assisted in identifying individual recognition in strengths to maximize potential and increase PsyCap. Other interventions have been found to support hope, self-efficacy, resilience, or optimism (HERO).

\section{Conclusion}

Overall, interventions from included studies showed effective improvement in HERO elements and increased PsyCap in individuals in academia and the workplace. In the context of the COVID-19 pandemic and future application, PsyCap interventions may be further explored and modified for virtual implementation for young adults.

Key Words

Psychological capital, PsyCap, Hope, Optimis*, Self-Efficac*, Resilienc*, Psychological capital 
intervention*, PsyCap intervention*, Virtual intervention*, Web-based intervention*, Intervention*, Productiv*, Performance, Procrast, efficienc*, motivation, Adult*, Young Adult*, Student*

\section{INTRODUCTION}

Psychological Capital (PsyCap) is an intrinsic positive and developmental state composed of four features: (1) Hope as one perseveres toward their goals; (2) Efficacy and confidence in one's competency; (3) Resilience in adversity; and (4) Optimism towards one's success (HERO) [1]. The concept of PsyCap emerged from positive psychology, which is defined as the study of well-being, productivity, optimal functioning, and expansion of an individual's full potential, with an emphasis on positive life experiences [1]. Over the last few decades, research has grown exponentially to find methods of integrating the ideas of positive psychology and psychological capital into daily life, the workplace and in education.

During the 1990s, Martin Seligman and his colleagues introduced the concept of positive psychology through their research on organizational behaviour [2]. For example, Positive Organizational Scholarship (POS), a sub-field in the area of MOS (Management and Organizations Studies), aims to integrate positive scientific principles (such as positive traits, states, processes, dynamics, and outcome) into organizations and professional environments. These scientific principles include: positive traits, states, processes, dynamics, and outcomes. In 2004, Luthans and his colleagues developed the concept of PsyCap, originating from the basis of positive psychology. "Psychological Capital" and "Positive Psychological Capital" are often used interchangeably by authors and sources. Further into his research, Luthans identified five psychological constructs (self-efficacy, hope, optimism, happiness, and resilience), labelled as POB (Positive Organisational Behaviour). This was further refined by Luthans and Youssef into four states (confidence, hope, optimism, resilience), now bundled into a higher-order construct known as "positive psychological capital" (PsyCap) [3]. This new framework was established to emphasize a sustainable competitive advantage as a holistic approach through human resources [4]. 
Figure 1. Expanding capital for competitive advantage

\begin{tabular}{|c|c|c|c|}
\hline $\begin{array}{l}\text { Traditional } \\
\text { economic } \\
\text { capital }\end{array}$ & $\begin{array}{c}\text { Human } \\
\text { capital }\end{array}$ & $\begin{array}{c}\text { Social } \\
\text { capital }\end{array}$ & $\begin{array}{c}\text { Positive } \\
\text { psychological } \\
\text { capital }\end{array}$ \\
\hline What you have & What you know & Who you know & Who you are \\
\hline $\begin{array}{l}\text { - Finances } \\
\text { - Tangible assets } \\
\text { (plant, equip- } \\
\text { ment, patents, } \\
\text { data) }\end{array}$ & $\begin{array}{l}\text { - Experience } \\
\text { - Education } \\
\text { - Skills } \\
\text { - Knowledge } \\
\text { - Ideas }\end{array}$ & $\begin{array}{l}\text { - Relationships } \\
\text { - Network of } \\
\text { contacts } \\
\text { - Friends }\end{array}$ & $\begin{array}{l}\text { - Confidence } \\
\text { - Hope } \\
\text { - Optimism } \\
\text { - Resilience }\end{array}$ \\
\hline
\end{tabular}

Fig. 1 Capital expansion from "Positive psychological capital: Beyond human and social Capital" (Luthans 2004 Pg. 46)

Luthans \& Youssef (2004) proposed the impacts of positive psychological management on the talents, strengths, and psychological capacities of an individual, thus leading to productive, ethical and sustainable outcomes [4]. In 2017, their research demonstrated that short training interventions positively influence PsyCap development [1]. Additionally, interventions used in positive clinical psychology, which can readily be adapted for the PsyCap model, had effectively improved positivity, alleviated negativity, and enhanced overall well-being [1]. These are crucial aspects to consider, as human personality and attitudes are subject to change over time. Additionally, PsyCap is more malleable than trait-like characteristics, which remain relatively fixed for adults. However, as PsyCap is relatively new, there is a gap in literature determining long-term effects through longitudinal studies to assess its full impact. As PsyCap derives its value from an intangible source (HERO -Who you are) reliant on self-perception, objectively measuring its value can be challenging [5].

Studies have shown that psychological capital plays a mediating role between stressful events and well-being [6]. Among 3123 university students in Shanghai, students' psychological capital was a negative predictor of anxiety [7]. Among students with high levels of academic burnout, the relationship between psychological capital and anxiety (bsimple $=-0.33, S E=0.03, p<$ 0.001 ) was stronger than those with low levels of academic burnout (bsimple $=-0.19, S E=0.03$, $p<0.001$ ) [7]. These figures support the hypotheses that those with low PsyCap are likely to suffer from negative emotions, anxiety and depression, and are less likely to effectively cope with stressful events. Consistent with these findings, Shen et al. (2014) found PsyCap to be negatively associated with depressive symptoms among 1,500 Chinese university teachers and PsyCap as a partial mediator of the effect of occupational stress on depressive symptoms $(\mathrm{R}=$ $-0.314, p<0.001$ ) [8]. These findings support the potential of PsyCap as a positive psychological resource that can be developed to manage anxiety and depressive symptoms. 
Studies in the past also suggest a relationship between PsyCap, workplace performance, and employee attitudes. A meta-analysis including studies with over 12,000 employees found PsyCap to be predictive of self-rated, supervisor-rated, objective performance, and desirable employee attitudes such as job satisfaction, commitment, and psychological well-being [9]. These findings correspond with findings among 235 other participants determining positive effects of PsyCap on employee job performance [10].

While relationships between PsyCap and anxiety, depression, and organizational performance are under investigation, there is a gap in literature synthesizing the findings of studies exploring the use of PsyCap interventions [7]. This is particularly important in the context of the COVID-19 pandemic, where psychological capital interventions have been suggested to effectively alleviate individuals' fear [11]. For example, among nurses in Pakistan, public health education interventions produced positive effects on psychological capital $(\beta=0.56, P<0.001)$, while psychological capital produced negative effects on fear of COVID-19 $(\beta=-0.24, P<0.001)$ [11]. In the context of organizational behaviours, the COVID-19 pandemic has resulted in drastic changes in learning and lifestyles as well [12]. Many employees and students resorted to abrupt transitions towards remote work and social distancing due to public health measures. Subsequent social isolation has directly influenced workers' perceptions of productivity and remote work satisfaction [13]. These findings further support a synthesis of PsyCap interventions and their relation to productivity.

To bridge the gap in the existing literature, this systematic review aims to assess the effectiveness of PsyCap development interventions. This will lead to the development of strategies that may be integrated towards virtual interventions, particularly within the development of the Felicity App. The Felicity App is a virtual application targeting younger demographics from 15-40 years of age. Thereby, this systematic review will determine effective interventions within the field of PsyCap to answer the research question: In young adults, (1) what are the effects of PsyCap development interventions? and (2) what is the relationship between PsyCap and productivity-related outcomes?

\section{METHODS}

A systematic review was conducted to investigate the effects of PsyCap development interventions and its relationship with productivity-related outcomes. Effective, evidence-based psychological capital interventions were drawn from existing literature to be integrated into a virtual application. The current review was conducted and reported in accordance with the Preferred Reporting Items for Systematic Reviews and Meta-Analyses (PRISMA) guidelines and registered within the PROSPERO database (with record ID of CRD42021245573).

\subsection{Search Strategy}


A systematic search of the literature was conducted on January 31, 2021 in APA PsychINFO, Web of Science, and PubMed to identify studies published between 1995 and 2020 which evaluated the impact of PsyCap interventions on productivity in adults between 15 and 40 years of age. Drawing on a combination of free-text search terms, Medical Subject Headings, and database-specific subject headings, a sensitive search strategy was developed for each electronic database, combining synonyms for "psychological capital", "intervention", "productivity", "support", and "adult" (refer to Appendix 1 for the full search strategy). To control publication bias, grey literature sources including conference proceedings in the Web of Science, Clinicaltrial.gov, and Frontiers were searched (refer to Appendix 2 for the grey literature search strategy). Further hand searching included screening of reference lists of included articles, with the last search performed on March 142021.

\subsection{Eligibility Criteria}

Studies followed a predetermined inclusion where studies were required to have a published date between January 1st 1990 and December 31st 2020 in the English language reporting either data on the outcomes of at least one intervention based on psychological capital and/or its components (hope, self-efficacy, resilience, optimism) or assessed the relationship between PsyCap and one or more productivity-related outcomes. Studies including at least 50 participants of both sexes between the ages of 15-40 years with no pre-existing medical conditions were included. The search was restricted to studies from developed countries. The exclusion criteria were 1) studies were conducted on populations with specific ethnicity, socioeconomic status, and/or educational background; and 2) duplicate records. Two authors (YAD, RK) independently searched through databases and included or excluded publications based on above-mentioned criteria. Any disagreements were resolved by further discussion.

\subsection{Data extraction and Quality Assessment}

The methodological quality of included studies was assessed by two authors (ARQ and CL) using the Mixed Methods Appraisal Tool (MMAT) version 2018 [14]. Data extraction was performed by two independent authors and reconciled. Study characteristics included the first author name, publication year, country, study design (cross-sectional, case-control, longitudinal studies), duration and participants, total sample size, type of data, and results. In case of any disagreement, a third author (YAD) reassessed the manuscript. 


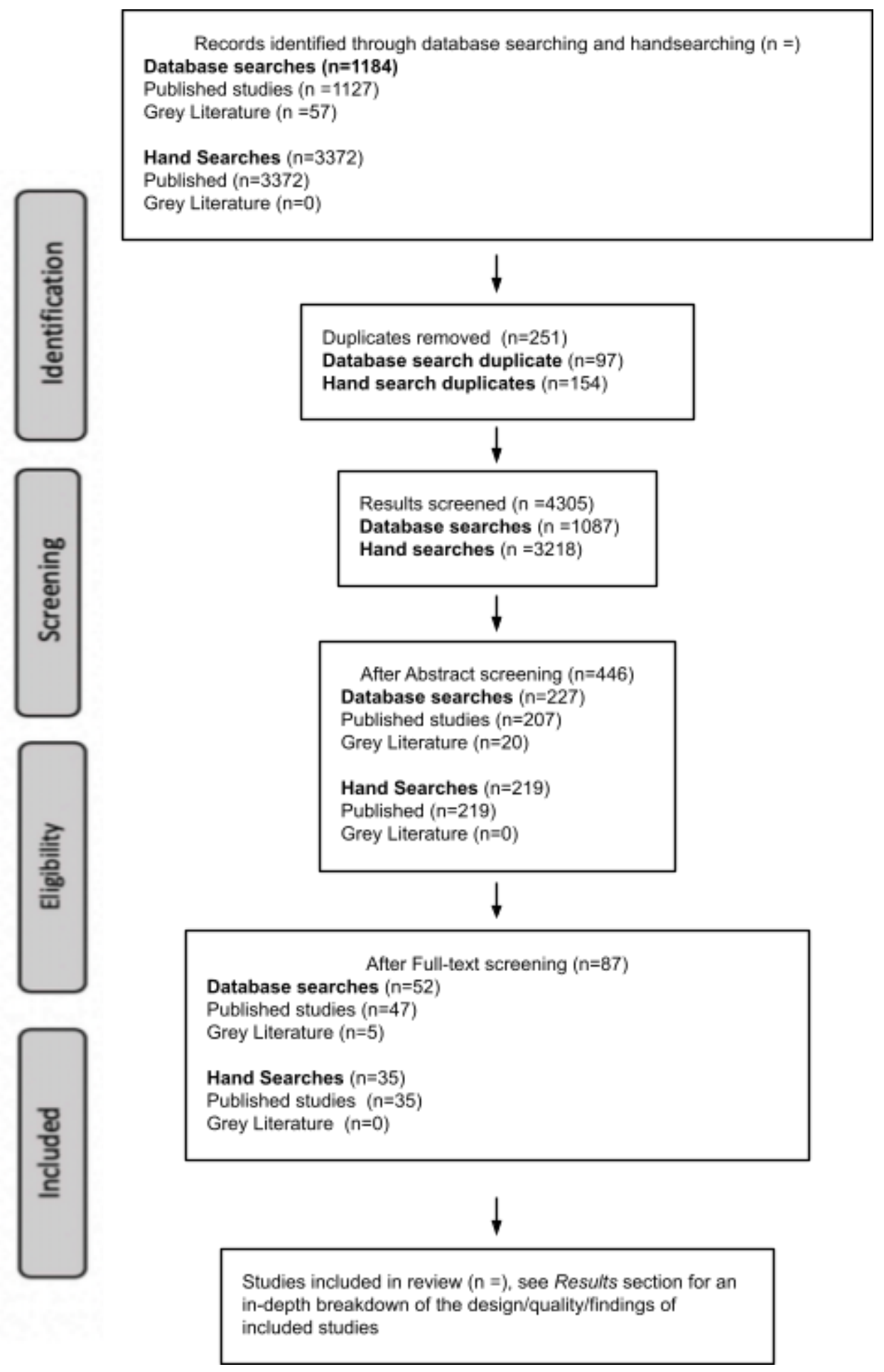

Fig. 2 Structural diagram of the screening and study selection processes completed 


\section{RESULTS}

\subsection{Study Selection}

Fig. 2 outlines the study selection and screening process. 1087 studies were initially identified, including: 58 grey literature, 1030 peer-reviewed studies, and 9 duplicates. All relevant published and grey literature underwent abstract screening and full-text screening. Post abstract-screening, a total of 227 studies remained, which included: 5 grey literature and 207 peer-reviewed studies. Post full-text screening, 52 studies remained, which included: 5 grey literature and 47 peer-reviewed studies. Through hand searches, 3218 peer-reviewed studies were identified, out of which 154 were duplicates. Post abstract-screening, a total of 219 studies remained -which were all peer-reviewed studies. Post full-text screening, a total of 35 peer-reviewed studies remained. In total, both database and hand searches combined, 87 studies remained, including 5 grey literature and 82 peer-reviewed studies. Refer to Appendix 4 for a list of excluded studies.

\subsection{Study Characteristics}

This review includes 85 peer-reviewed articles: 32 are non-randomized studies, 14 are quantitative descriptive studies, 14 are randomized control trials (RCT), 7 are qualitative studies, 6 are mixed methods studies, and 12 are non-empirical studies. Of these papers, 30 studies are from the USA; 9 from Netherlands; 8 from each of China and Spain; 4 from Australia; 2 from each of Turkey, the United Kingdom, Italy and Greece; 1 from each of Germany, Finland, Portugal, Iran, Ireland, Taiwan, Israel, France and Sweden; and 7 are unspecified (non-empirical studies). The data was categorized into 4 types of data; questionnaires, qualitative data, interviews or a combination of qualitative and quantitative data. From the 85 articles, 54 studies were questionnaires, 2 studies used qualitative data, 4 studies used interview data, and 10 studies used a combination of qualitative and quantitative data. The studies were rated based on the MMAT 5-point scale, in which the highest rank on the scale is 5 and the lowest rank is 1 . In the collection of 85 articles, 6 articles were rated 5, 15 articles were rated 4, 31 articles were rated 3, 14 articles were rated 2, while 7 articles were rated 1. Refer to Appendix 3 for the full study characteristics table.

\subsection{Findings}

Studies rated under 3 out of 5 according to the MMAT tool and/or non empirical papers were excluded. 58 articles were empirical studies rated above 3, of which 32 (55.2\%) found that an intervention resulted in an increase in PsyCap and/or at least 1 dimension, 3 (5.2\%) found that the intervention did not improve PsyCap and/or at least 1 dimension, 20 (34.5\%) found PsyCap to be related to productivity outcomes, $1(1.7 \%)$ found that PsyCap was unrelated to productivity outcomes, and $2(3.4 \%)$ have either inconclusive results or results that were not relevant to the research question of this study.

\subsection{Outcomes}


The major outcomes were only considered for articles that were rated 5 out of $5(n=4)$ using the MMAT (Table 1). 3 out of these 5 studies found an intervention to increase PsyCap and 1 found no effect on PsyCap.

Table 1 . Findings and outcomes of articles that were rated $5 / 5(n=4)$

\begin{tabular}{|l|l|l|}
\hline Article & Finding & Outcome \\
\hline $\begin{array}{l}\text { Rizzato 2014, A brief online } \\
\text { loving-kindness meditation } \\
\text { intervention; effects on } \\
\text { optimism and affect [x] }\end{array}$ & $\begin{array}{l}\text { Intervention did not } \\
\text { improve PsyCap } \\
\text { and/or any of its } \\
\text { dimensions. }\end{array}$ & $\begin{array}{l}\text { Despite increasing Positive Affect } \\
\text { scores, the results demonstrated a } \\
\text { loving-kindness intervention to } \\
\text { result in no significant differences } \\
\text { between intervention groups and } \\
\text { control groups. }\end{array}$ \\
\hline $\begin{array}{l}\text { McGonagle 2020, Coaching for } \\
\begin{array}{l}\text { Wrimary Care Physician } \\
\text { Tril-Being: A Randomized } \\
\text { [x] }\end{array}\end{array}$ & $\begin{array}{l}\text { Intervention improved Follow-Up Analysis } \\
\text { PsyCap and/or any of } \\
\text { its dimensions. }\end{array}$ & $\begin{array}{l}\text { Coaching is a helpful intervention } \\
\text { for improving PCP } \\
\text { burnout, engagement, and } \\
\text { psychological capital. }\end{array}$ \\
\hline $\begin{array}{l}\text { Luthans 2008, Experimental } \\
\text { Analysis of a Web-Based } \\
\text { Training Intervention to } \\
\begin{array}{l}\text { Develop Positive Psychological } \\
\text { Capital [x] }\end{array}\end{array}$ & $\begin{array}{l}\text { Intervention improved } \\
\text { PsyCap and/or any of } \\
\text { its dimensions. }\end{array}$ & $\begin{array}{l}\text { Web-based psychological } \\
\text { development interventions can } \\
\text { provide competitive advantage for } \\
\text { organizations. }\end{array}$ \\
\hline $\begin{array}{l}\text { Meyers 2016, Effects of a } \\
\text { Strengths Intervention on } \\
\text { General } \\
\text { and Work-Related Well-Being: } \\
\text { The Mediating Role } \\
\text { of Positive Affect [x] }\end{array}$ & $\begin{array}{l}\text { Intervention improved } \\
\text { PsyCap and/or any of } \\
\text { its dimensions. }\end{array}$ & $\begin{array}{l}\text { Participating in a strengths } \\
\text { intervention creates short-term } \\
\text { increases in employee positive } \\
\text { affect and short- and long-term } \\
\text { increases in psychological capital. }\end{array}$ \\
\hline
\end{tabular}

\section{DISCUSSION}

\section{Relationship of PsyCap and Productivity}

Several of the included studies $(n=19)$ assessed the relationship between PsyCap and productivity. 6 studies out of 19 focused on the extent to which PsyCap enhances undergraduate students' long-term performance, and 13 studies researched how PsyCap can impact job-search behaviour and employees' job satisfaction/performance.

(a) Undergraduate students 
2 of 6 studies investigated how PsyCap interventions improve undergraduate students' ability to cope with stress, and their overall satisfaction. Measurements of PsyCap demonstrated direct effects on performance and satisfaction [15]. This is further supported by how cognitive-behaviour interventions, which were designed to increase self-efficacy, engagement and performance, resulted in higher levels of academic performance at follow-up [16]. Additionally, PsyCap equips students to perform better in both an online and in a workplace setting [12]. However, it should be noted that PsyCap strategies on their own are not sufficient to improve productivity. Meaning-focused coping, using acceptance, humour and positive reframing, may have reinforced students' PsyCap to persevere in achieving their academic goals [15]. Beyond the Psychological Capital Intervention (PCI), PsyCap-enhancing strategies for students include interval coaching through teacher-student interactions or other forms of mentoring relationships [17].

\section{(b) Workplace}

PsyCap levels are positively related to enhanced job-seekers' job-search behaviour and goal setting [18]. Job-seekers who followed a PsyCap training method were more likely to be employed 3 months following the intervention relative to the control control-group [19]. In a Chinese cultural context, a leader's PsyCap significantly and positively influences the PsyCap of their subordinates, which relies on how the leader's attitude is perceived [20]. A leaders' humble attitude contributes to greater psychological safety, resulting in a higher team PsyCap. Enhancing employees' PsyCap strengthens their capacity to cope with job demands more efficiently compared to common compensation systems and organizational redesign [21]. Having followed a PsyCap-enhancing intervention, employees experienced higher levels of engagement at work. This can be explained by how employees, having now understood the dimension of PsyCap, are better equipped to cope with their perceived symptoms of job stress.

\section{Interventions}

\section{(a) PCI Intervention}

A number of the included studies $(n=8)$ used a PCI-based model to positively impact the development of PsyCap in participants. The PCI model, developed by Fred Luthans, increases PsyCap by selectively targeting and enhancing the four resources of PsyCap (HERO) through specialized techniques revolving around the creation and achievement of goals [22]. The PCI model has been adapted into many organizational and virtual settings as a micro-intervention training to increase the PsyCap of individuals in both professional and academic settings [22,23].

In 4 of the 8 studies, the PCI model targeted all four components of HERO through a 2-hour online/modular training intervention. Hope is developed by the identification of personal and challenging goals and the development of pathways to achieve those goals, while receiving feedback through group discussions [22]. Resilience is developed by allowing individuals to 
derive multiple different pathways to achieve their goals. In addition, the participants are asked to list their personal assets and identify obstacles towards achieving their goals as a way to further develop resilience [22,24,25]. Optimism is developed by the general positive expectations that come as a result of establishing a plan for goal achievement. Finally, efficacy is developed through the PCI intervention by creating a stepwise technique to accomplish goals through the creation of subgoals, and attaining task mastery for goal creation [19].

Ultimately, Luthan's PCI intervention model and derivations of the model have been supported by all the included studies to be effective in increasing the total PsyCap of individuals, as measured by the PsyCap Questionnaire preceding and following the intervention [19,22,24-26].

\section{(b) Interventions Impacting Total PsyCap}

A variety of other interventions were investigated by 13 of the included studies to increase total PsyCap of individuals. The most significant interventions derived from these studies include the strengths-based intervention, as discussed by 3 of the 13 studies, and a mindfulness training intervention, discussed in 2 of the 13 studies.

The strengths-based intervention training is designed to identify strengths in an individual and encourage the use of these strengths to their maximum potential to promote wellbeing, and ultimately increase PsyCap [27,28]. The strengths-based intervention is carried out in different forms. One example of the strengths-based intervention is found in a study conducted by Meyers and van Woerkom, in which a half day strengths identification intervention was performed as a preparatory assignment to discover an individual's three most dominant strengths. 24 strengths were presented as cards to prompt individuals to identify personal talents [27]. This intervention was deemed successful and indicated short-term increases in PsyCap during the one-month follow up of the intervention, as measured by a 16-item measure with a 4-item self-efficacy scale $[20]$.

The mindfulness training intervention is a 9-week training intervention in which participants are able to gain relevant knowledge about meditation and mindfulness, and then spend the remainder of the intervention period focusing on their bodies by the implementation of body scanning training, focus on awareness thinking, meditation breathing, kindness meditation, and respiratory space training [29]. This mindfulness intervention is able to decrease self-cognition bias and automatic negative emotional responses by expanding consciousness and promoting positive emotions [22]. It is evident that the automatic negative response of those who encounter difficult obstacles in their pathway to goal achievement manifested into procrastination [22]. As a result, mindfulness decreases the negative emotional response and promotes the four positive psychological resources of PsyCap (HERO) ultimately increasing total PsyCap [22, 23]. The studies indicate that the intervention group reported increased self-efficacy, hope, resilience, and total PsyCap in comparison to the control group [30]. 


\section{(c) Interventions Impacting HERO}

Apart from the PCI model, 6 studies outlined interventions that improved one or more of the resources within PsyCap rather than the development of PsyCap overall. Of the 8 studies, 1 study examined the development of resilience through a work-site resiliency training program called personal resilience and resilient relationships [31]. The intervention was facilitated by a single trainer and aimed at uncovering the internal resilience of workers and the use of strategies to overcome obstacles at the workplace.

To develop hope, Feldman and Dreher outlined a 90-minute intervention involving goal setting and goal visualization in a similar fashion to PCI [32]. However, due to the short duration of the intervention, long-term measurements of hope revealed a decrease in the initial effects on hope achieved by the intervention [25].

Kosenkranius et al. outlined an intervention that increases self-efficacy in a group setting [33]. While the study highlighted an off-job crafting intervention to develop factors apart from self-efficacy, the sharing of a past success with others was intended to increase a participant's self-efficacy [26].

Out of the four resources that make up PsyCap, the development of optimism was discussed in 3 studies. Two of the studies discussed a daily optimism intervention. A best possible self (BPS) intervention involved participation in imagery tasks where individuals were instructed to think about how they wanted to be remembered within three domains: 1) personal domain, 2) relational domain and 3) professional domain [34,35]. After one week of the BPS intervention, the authors observed an increase in measurements of optimism [27]. Another study focused on a daily optimism intervention that asked participants to list three positive things that the individuals were expecting to occur the next day. While this intervention did not result in an increase in optimism measurements, there were decreases in measurements in pessimism, thus resulting in a positive outcome [36].

\section{Strengths and Limitations}

Qualitative, quantitative, and mixed methods studies were examined for this systematic review. The mixed methods design provides a holistic view of the findings by incorporating both qualitative and quantitative data. Data were collected from a diverse pool of literature that focused on key concepts related to psychological capital interventions and HERO. Beyond the quantitative findings, excerpts were analyzed from qualitative studies on the target age group to reveal the qualitative impact of psychological capital interventions on an individual's success to allow a thorough analysis of the benefits and limitations of various interventions. 
The systematic review includes studies from many regions within North America, Europe, and Asia. 33 studies were conducted in all countries in North America; 27 studies were conducted in Europe, encompassing the Eastern, Northern, Southern, and Western regions; 13 studies were conducted in Asia, encompassing the East, South East, and Middle East regions. Data were extracted from a variety of countries and populations to analyze the impact of psychological capital and psychological capital interventions on individual success in professional and workplace settings. Only studies that were written in English language were included in the systematic review which may limit the scope of the literature collection. As the Felicity app will be mostly accessible to members of these regions and of the 15-40 year old age demographic, measures were taken to ensure that the literature collected is representative of the target population. A limitation arose during the quality appraisal process of the studies, in which the MMAT ratings varied through objectivity. Quality assessors discussed MMAT rating criteria prior to appraising to reduce subjectivity. Due to the heterogeneity of study design and findings, further research (including additional quality assessment and statistical analysis) is required to determine the efficacy of virtual interventions within PsyCap.

\section{CONCLUSION}

Based on the studies discussed, PsyCap was found to have an effect on productivity in both an educational and workplace setting. To increase PsyCap, several interventions were highlighted and shown to result in developments of the four resources within PsyCap. Specifically, interventions surrounding mindfulness, strength-based interventions, and the psychological capital intervention (PCI) all demonstrated increases in PsyCap. Most notably, interventions such as PCI were found to be implemented in the form of micro-interventions that could be adapted to a virtual setting. Thus, PCI among other studies effectively discuss methods of implementing PsyCap interventions virtually. 


\section{REFERENCES}

[1] Luthans F, Youssef-Morgan CM. Psychological Capital: An Evidence-Based Positive Approach. Annu Rev Organ Psychol Organ Behav. 2017;4(1):339-66.

[2] ÇAVUŞ M, Kapusuz A. Psychological Capital: Definition, Components and Effects. Br J Educ Soc Behav Sci. 2015 Mar 1;5:244-55.

[3] Lorenz T, Beer C, Pütz J, Heinitz K. Measuring Psychological Capital: Construction and Validation of the Compound PsyCap Scale (CPC-12). PLoS ONE [Internet]. 2016 Apr 1 [cited 2021 Apr 11];11(4). Available from: https://www.ncbi.nlm.nih.gov/pmc/articles/PMC4817957/

[4] Luthans F, Youssef CM. Human, Social, and Now Positive Psychological Capital Management: Organ Dyn. 2004 May;33(2):143-60.

[5] Luthans F, Luthans KW, Luthans BC. Positive psychological capital: beyond human and social capital. Bus Horiz. 2004 Jan;47(1):45-50.

[6] Yang Q. College Students' Pressure and Subjective Well-Being: The Mediator of Psychological Capital and The Moderator of Social Support. [SiChuan]. SiChuan Normal University; 2016.

[7] Jiang Y. Problematic Social Media Usage and Anxiety Among University Students During the COVID-19 Pandemic: The Mediating Role of Psychological Capital and the Moderating Role of Academic Burnout. Front Psychol [Internet]. 2021 [cited 2021 Apr 11];12. Available from: https://www.frontiersin.org/articles/10.3389/fpsyg.2021.612007/full\#B8

[8] Shen X, Yang Y-L, Wang Y, Liu L, Wang S, Wang L. The association between occupational stress and depressive symptoms and the mediating role of psychological capital among Chinese university teachers: a cross-sectional study. BMC Psychiatry [Internet]. 2014 Nov 30 [cited 2021 Apr 11];14. Available from: https://www.ncbi.nlm.nih.gov/pmc/articles/PMC4261521/

[9] Avey JB, Reichard RJ, Luthans F, Mhatre KH. Meta-analysis of the impact of positive psychological capital on employee attitudes, behaviors, and performance. Hum Resour Dev Q. 2011;22(2):127-52.

[10] Tüzün IK, Çetin F, Basim HN. Improving job performance through identification and psychological capital. Int J Product Perform Manag. 2018 Jan 1;67(1):155-70.

[11] Mubarak N, Safdar S, Faiz S, Khan J, Jaafar M. Impact of public health education on undue fear of COVID-19 among nurses: The mediating role of psychological capital. Int J Ment Health Nurs [Internet]. 2020 Nov 23 [cited 2021 Apr 11]; Available from: https://www.ncbi.nlm.nih.gov/pmc/articles/PMC7753350/

[12] Black D, Bissessar C, Boolaky M. The missing HEROs: the absence of, and need for, PsyCap research of online university students. Open Learn J Open Distance E-Learn. 2020 Dec 7;0(0):1-19.

[13] Toscano F, Zappalà S. Social Isolation and Stress as Predictors of Productivity Perception and Remote Work Satisfaction during the COVID-19 Pandemic: The Role of Concern about the Virus in a Moderated Double Mediation. Sustainability. 2020 Jan;12(23):9804.

[14] Hong QN, Fàbregues S, Bartlett G, Boardman F, Cargo M, Dagenais P, et al. The Mixed Methods Appraisal Tool (MMAT) version 2018 for information professionals and researchers. Educ Inf. 2018 Nov 12;34:1-7. 
[15] Ortega-Maldonado A, Salanova M. Psychological capital and performance among undergraduate students: the role of meaning-focused coping and satisfaction. Teach High Educ. $2018 \mathrm{Apr}$ 3;23(3):390-402.

[16] Bresó E, Schaufeli WB, Salanova M. Can a self-efficacy-based intervention decrease burnout, increase engagement, and enhance performance? A quasi-experimental study. High Educ. 2011 Apr 1;61(4):339-55.

[17] Luthans KW, Luthans BC, Chaffin TD. Refining Grit in Academic Performance: The Mediational Role of Psychological Capital. J Manag Educ. 2019 Feb 1;43(1):35-61.

[18] Hulshof IL, Demerouti E, Le Blanc PM. A job search demands-resources intervention among the unemployed: Effects on well-being, job search behavior and reemployment chances. J Occup Health Psychol. 2020 Feb;25(1):17-31.

[19] Georgiou K, Nikolaou I, Turban DB. The Impact of a Training Intervention Developing Psychological Capital on Job Search Success. J Career Dev. 2019 Jun 17;0894845319852425.

[20] Chen Q, Kong Y, Niu J, Gao W, Li J, Li M. How Leaders' Psychological Capital Influence Their Followers' Psychological Capital: Social Exchange or Emotional Contagion. Front Psychol [Internet]. 2019 [cited 2021 Apr 10];10. Available from: https://www.frontiersin.org/articles/10.3389/fpsyg.2019.01578/full

[21] Costantini A, De Paola F, Ceschi A, Sartori R, Meneghini A, Fabio A. Work engagement and psychological capital in the Italian public administration: A new resource-based intervention programme. SA J Ind Psychol. 2017 Jul 25;43.

[22] Luthans BC, Luthans KW, Avey JB. Building the Leaders of Tomorrow: The Development of Academic Psychological Capital. J Leadersh Organ Stud. 2014 May 1;21(2):191-9.

[23] Luthans F, Avey JB, Avolio BJ, Norman SM, Combs GM. Psychological capital development: toward a micro-intervention. J Organ Behav. 2006 May;27(3):387-93.

[24] Luthans F, Avey JB, Patera JL. Experimental Analysis of a Web-Based Training Intervention to Develop Positive Psychological Capital. Acad Manag Learn Educ. 2008 Jun;7(2):209-21.

[25] Luthans F, Avey JB, Avolio BJ, Peterson SJ. The development and resulting performance impact of positive psychological capital. Hum Resour Dev Q. 2010 Dec;21(1):41-67.

[26] Liang L, Xiao Q, Yang Y. The Psychological Capital of Left-Behind University Students: A Description and Intervention Study From China. Front Psychol [Internet]. 2018 [cited 2021 Apr 10];9. Available from: https://www.frontiersin.org/articles/10.3389/fpsyg.2018.02438/full

[27] Meyers MC, van Woerkom M. Effects of a strengths intervention on general and work-related well-being: The mediating role of positive affect. J Happiness Stud Interdiscip Forum Subj Well-Being. 2017;18(3):671-89.

[28] Corbu A, Peláez Zuberbühler MJ, Salanova M. Positive Psychology Micro-Coaching Intervention: Effects on Psychological Capital and Goal-Related Self-Efficacy. Front Psychol [Internet]. 2021 [cited 2021 Apr 10];12. Available from: https://www.frontiersin.org/articles/10.3389/fpsyg.2021.566293/full

[29] Li L, Li M. Effects of Mindfulness Training on Psychological Capital, Depression, and Procrastination of the Youth Demographic. Iran J Public Health. 2020 Aug 23;49(9):1692-700. 
[30] Barry KM, Woods M, Martin A, Stirling C, Warnecke E. A randomized controlled trial of the effects of mindfulness practice on doctoral candidate psychological status. J Am Coll Health J ACH. 2019 Jun;67(4):299-307.

[31] Waite PJ, Richardson GE. Determining the efficacy of resiliency training in the work site. J Allied Health. 2004;33(3):178-83.

[32] Feldman DB, Dreher DE. Can Hope be Changed in 90 Minutes? Testing the Efficacy of a Single-Session Goal-Pursuit Intervention for College Students. J Happiness Stud. 2012 Aug 1;13(4):745-59.

[33] Kosenkranius MK, Rink FA, de Bloom J, van den Heuvel M. The design and development of a hybrid off-job crafting intervention to enhance needs satisfaction, well-being and performance: a study protocol for a randomized controlled trial. BMC Public Health. 2020 Jan 28;20(1):115.

[34] Peters ML, Meevissen YMC, Hanssen MM. Specificity of the Best Possible Self intervention for increasing optimism: Comparison with a gratitude intervention. Ter Psicológica. 2013 Apr;31(1):93-100.

[35] Meevissen YMC, Peters ML, Alberts HJEM. Become more optimistic by imagining a best possible self: effects of a two week intervention. J Behav Ther Exp Psychiatry. 2011 Sep;42(3):371-8.

[36] Littman-Ovadia H, Nir D. Looking forward to tomorrow: The buffering effect of a daily optimism intervention. J Posit Psychol. 2014 Mar 4;9(2):122-36.

[37] Li S, Li H, Xu C. Research on Psychological Capital Intervention of College Students. In Atlantis Press; 2018 [cited 2021 Apr 10]. p. 211-4. Available from:

https://www.atlantis-press.com/proceedings/iserss-18/25899499

[38]Diedrich T. Psychological capital: An intervention method for developing organization leadership in a mental health center [Internet] [Dissertation]. Benedictine University,; 2015 [cited 2021 Apr 10]. Available from:

https://search.proquest.com/openview/5fd15edcd2250a79793f11081d0ab18a/1?pq-origsite=gscholar $\& \mathrm{cbl}=18750 \&$ diss $=\mathrm{y}$

[39] Devall-Martin LM. School Administrators' Insight and Self-reflection: An exploration of the influence of expressive writing and the LuminaSpark (C) inventory on self-awareness [Internet] [Thesis]. Johns Hopkins University; 2017 [cited 2021 Apr 10]. Available from: https://dspace-prod.mse.jhu.edu/handle/1774.2/44714

[40] Agarwal P, Farndale E. High-performance work systems and creativity implementation: the role of psychological capital and psychological safety. Human Resource Management Journal. 2017;27(3):440-58.

[41] Akkermans J, Brenninkmeijer V, Schaufeli WB, Blonk RWB. It's All About CareerSKILLS: Effectiveness of a Career Development Intervention for Young Employees. Human Resource Management. 2015;54(4):533-51.

[42] Avey JB, Luthans F, Jensen SM. Psychological capital: A positive resource for combating employee stress and turnover. Human Resource Management. 2009;48(5):677-93. 
[43] Avey JB, Luthans F, Youssef CM. The Additive Value of Positive Psychological Capital in Predicting Work Attitudes and Behaviors. Journal of Management. 2010 Mar 1;36(2):430-52.

[44] Bonner L. A survey of work engagement and psychological capital levels. Br J Nurs. 2016 Aug 11;25(15):865-71.

[45] Burns AJ. The impact of organizational insiders' psychological capital on information security. Doctoral Dissertations [Internet]. 2013 Oct 1; Available from: https://digitalcommons.latech.edu/dissertations/270

[46] Burns AJ, Posey C, Roberts TL, Benjamin Lowry P. Examining the relationship of organizational insiders' psychological capital with information security threat and coping appraisals. Computers in Human Behavior. 2017 Mar 1;68:190-209.

[47] Carter JW, Youssef-Morgan CM. The positive psychology of mentoring: A longitudinal analysis of psychological capital development and performance in a formal mentoring program. Human Resource Development Quarterly. 2019;30(3):383-405.

[48] Cenciotti R, Alessandri G, Borgogni L. Psychological Capital and Career Success Over Time: The Mediating Role of Job Crafting. Journal of Leadership \& Organizational Studies. 2017 Aug $1 ; 24(3): 372-84$.

[49] Cesaro RJ. Psychological Capital as a Mediator Between Team Cohesion and Productivity. $2016 ; 104$.

[50]Clauss E, Hoppe A, O’Shea D, González Morales MG, Steidle A, Michel A. Promoting personal resources and reducing exhaustion through positive work reflection among caregivers. Journal of Occupational Health Psychology. 2018;23(1):127-40.

[51] Da S, He Y, Zhang X. Effectiveness of Psychological Capital Intervention and Its Influence on Work-Related Attitudes: Daily Online Self-Learning Method and Randomized Controlled Trial Design. International Journal of Environmental Research and Public Health. 2020 Jan;17(23):8754.

[52] Dorling JL. Impact of psychological capital on the resistance to change during post-merger integration: A theoretical model. Journal of Organizational Change Management. 2017 Jan 1;30(6):936-56.

[53]Ertosun ÖG, Erdil O, Deniz N, Alpkan L. Positive Psychological Capital Development: A Field Study by the Solomon Four Group Design. International Business Research. 2015 Sep 25;8(10):p102.

[54]Fontes A, Russo SD. An Experimental Field Study on the Effects of Coaching: The Mediating Role of Psychological Capital. Applied Psychology. 2021;70(2):459-88.

[55]Fu Y. Promoting effect of traditional music education on the psychological capital of college students. Revista Argentina de Clínica Psicológica. 2020;29(1):918-24. 
[56] Georgiou K, Nikolaou I. The influence and development of psychological capital in the job search context. Int J Educ Vocat Guidance. 2019 Oct 1;19(3):391-409.

[57] Goertzen B, Whitaker B. Development of psychological capital in an academic-based leadership education program. The Journal of Management Development. 2015 Jul 13;34.

[58] Gonçalves L, Brandão F. The relation between leader's humility and team creativity: The mediating effect of psychological safety and psychological capital. International Journal of Organizational Analysis. 2017 Jul 17;25:00-00.

[59] Gooty J, Gavin M, Johnson P, Frazier M, Snow D. In the Eyes of the Beholder: Transformational Leadership, Positive Psychological Capital, and Performance. Journal of Leadership \& Organizational Studies - J Leader Organ Stud. 2009 May 1;15:353-67.

[60] Hargrove MB. Antecedents And Outcomes Associated With The Individual Stress Response. 2013 Mar 20 [cited 2021 Apr 10]; Available from: https://rc.library.uta.edu/uta-ir/handle/10106/11508

[61] Harty B, Gustafsson J-A, Björkdahl A, Möller A. Group intervention: A way to improve working teams' positive psychological capital. Work. 2015;53(2):387-98.

[62] Hodges T. An Experimental Study of the Impact of Psychological Capital on Performance, Engagement, and the Contagion Effect. Dissertations, Theses, and Student Research from the College of Business [Internet]. 2010 Jan 1; Available from:

https://digitalcommons.unl.edu/businessdiss/7

[63] Houston JB, First J, Spialek ML, Sorenson ME, Mills-Sandoval T, Lockett M, et al. Randomized controlled trial of the Resilience and Coping Intervention (RCI) with undergraduate university students. Journal of American College Health. 2017 Jan 2;65(1):1-9.

[64] KALMAN M, SUMMAK MS. Revitalizing the HERO within Teachers: An Analysis of the Effects of the PsyCap Development Training. The Qualitative Report. 2017 Mar 4;22(3):655-82.

[65] Khajavy GH, Makiabadi H, Abdinavokhi S. The Role of Psychological Capital in Language Learners' Willingness to Communicate, Motivation, and Achievement. Eurasian Journal of Applied Linguistics. 2019 Nov 26;5:495-513.

[66] Khan H. Engineering Positive Organizational Behavior and managing the Psychological Capital for learning effectiveness. In: 2011 Frontiers in Education Conference (FIE). 2011. p. S2C-1-S2C-6.

[67]Lin C-C, Kao Y-T, Chen Y-L, Lu S-C. Fostering Change-Oriented Behaviors: A Broaden-and-Build Model. J Bus Psychol. 2016 Sep 1;31(3):399-414.

[68] Lupşa D, Vîrga D, Maricuțoiu LP, Rusu A. Increasing Psychological Capital: A Pre-Registered Meta-Analysis of Controlled Interventions. Applied Psychology. 2020;69(4):1506-56.

[69] Luthans F. Psychological capital: Implications for HRD, retrospective analysis, and future directions. Human Resource Development Quarterly. 2012;23(1):1-8. 
[70] Luthans F, Vogelgesang GR, Lester PB. Developing the Psychological Capital of Resiliency. Human Resource Development Review. 2006 Mar 1;5(1):25-44.

[71] Luthans KW, Luthans BC, Palmer NF. A positive approach to management education: The relationship between academic PsyCap and student engagement. Journal of Management Development. 2016;35(9):1098-118.

[72] Malouff JM, Schutte NS. Can psychological interventions increase optimism? A meta-analysis. The Journal of Positive Psychology. 2017 Nov 2;12(6):594-604.

[73] McGonagle AK, Schwab L, Yahanda N, Duskey H, Gertz N, Prior L, et al. Coaching for primary care physician well-being: A randomized trial and follow-up analysis. J Occup Health Psychol. 2020 Oct;25(5):297-314.

[74] Medhurst A, Albrecht S. Salesperson engagement and performance: A theoretical model. Journal of Management \& Organization. 2011 May 1;17:398-411.

[75] Meyers MC, van Woerkom M, de Reuver RSM, Bakk Z, Oberski DL. Enhancing psychological capital and personal growth initiative: working on strengths or deficiencies. J Couns Psychol. 2015 Jan;62(1):50-62.

[76] Mills MJ, Fleck CR, Kozikowski A. Positive psychology at work: A conceptual review, state-of-practice assessment, and a look ahead. The Journal of Positive Psychology. 2013 Mar $1 ; 8(2): 153-64$.

[77] Monnot MJ. Organizational change agent influence: A conditional process model of key individual psychological resources. Journal of Change Management. 2017;17(3):268-95.

[78] Ouweneel E, Le Blanc PM, Schaufeli WB. Do-it-yourself: An online positive psychology intervention to promote positive emotions, self-efficacy, and engagement at work. The Career Development International. 2013;18(2):173-95.

[79] Peláez Zuberbuhler MJ, Salanova M, Martínez IM. Coaching-Based Leadership Intervention Program: A Controlled Trial Study. Front Psychol [Internet]. 2020 [cited 2021 Apr 10];10. Available from: https://www.frontiersin.org/articles/10.3389/fpsyg.2019.03066/full

[80]Reichard R, Dollwet M, Louw-Potgieter J. Development of Cross-Cultural Psychological Capital and Its Relationship With Cultural Intelligence and Ethnocentrism. Journal of Leadership \& Organizational Studies. 2013 Apr 25;21:150-64.

[81] Rizzato M. A brief online loving-kindness meditation intervention; effects on optimism and affect. 2014 [cited 2021 Apr 10]; Available from: https://esource.dbs.ie/handle/10788/2212

[82] Ruderman M, Clerkin C. Developing Leadership by Building Psychological Capital. 2015.

[83] Sharp R. Career crescendo: An experimental analysis of a 6-week work-site intervention to determine the developmental capacity of psychological capital. Journal of Management Development. 2019 Jan 1;38(9):719-32. 
[84] Stratman JL, Youssef-Morgan CM. Can positivity promote safety? Psychological capital development combats cynicism and unsafe behavior. Safety Science. 2019 Jul 1;116:13-25.

[85] van Wingerden J, Bakker AB, Derks D. A test of a job demands-resources intervention. Journal of Managerial Psychology. 2016;31(3):686-701.

[86] Verleysen B, Lambrechts F, Van Acker F. Building Psychological Capital With Appreciative Inquiry: Investigating the Mediating Role of Basic Psychological Need Satisfaction. The Journal of Applied Behavioral Science. 2015 Mar 1;51(1):10-35.

[87] Williams P, Kern ML, Waters L. Exploring Selective Exposure and Confirmation Bias as Processes Underlying Employee Work Happiness: An Intervention Study. Front Psychol [Internet]. 2016 [cited 2021 Apr 10];7. Available from: https://www.frontiersin.org/articles/10.3389/fpsyg.2016.00878/full

[88] Youssef-Morgan CM. Advancing OB Research: An Illustration Using Psychological Capital. Journal of Leadership \& Organizational Studies. 2014 May 1;21(2):130-40.

[89]Zhang X, Li Y-L, Ma S, Hu J, Jiang L. A structured reading materials-based intervention program to develop the psychological capital of Chinese employees. Social Behavior and Personality. 2014 Mar 20;42(3):503.

[90]Zhao Y. Promoting effect of psychological capital construction of college students on english teaching. Revista argentina de clínica psicológica. 2020;29(1):1240-5. 


\section{DECLARATIONS}

Funding: This systematic review was funded in part by a grant from The Duke of Edinburgh's International Award through the P2P program in partnership with the federal government of Canada.

\section{Conflicts of interest/Competing interests:}

The author(s) declared no potential conflicts of interest with respect to the research, authorship, and/or publication of this article.

\section{Availability of data and material:}

N/A

\section{Code availability:}

$\mathrm{N} / \mathrm{A}$

\section{Authors' contributions:}

JX devised and supervised the project and secured funding acquisition. ARQ, YAD, CL and RK designed the protocol and search articles, YAD and RK completed preliminary and full-text screenings, ARQ, YAD, RK and CL completed hand searches, ARQ and CL completed quality assessment and data extraction. ARQ created figured and computed numerical data, YAD, RK, $\mathrm{ARQ}$, and CL equally wrote the manuscript. All authors reviewed the final manuscript.

\section{APPENDICES}

\section{Appendix 1:}

Database Searches - January 31, 2021

- PsychInfo: Group 1 AND (Group 2 or Group 3)

- Web of Science: Group 1 AND Group 2 AND Group 3

- PubMed: Group 1 AND Group 2 AND Group 3 AND Group 4

\begin{tabular}{|c|c|c|c|c|}
\hline & $\begin{array}{l}\text { Psychological } \\
\text { capital - Group } 1\end{array}$ & Intervention - Group 2 & $\begin{array}{l}\text { Productivity - Group } \\
3\end{array}$ & Population \\
\hline $\begin{array}{l}\text { Free-text } \\
\text { terms }\end{array}$ & $\begin{array}{l}\text { Psychological } \\
\text { capital } \\
\text { PsyCap } \\
\text { Hope } \\
\text { Optimis* }\end{array}$ & $\begin{array}{l}\text { Psychological capital } \\
\text { intervention* } \\
\text { PsyCap intervention* } \\
\text { Virtual intervention* } \\
\text { Web-based }\end{array}$ & $\begin{array}{l}\text { Productiv* } \\
\text { Performance } \\
\text { Procrast* } \\
\text { efficienc* } \\
\text { motivation }\end{array}$ & $\begin{array}{l}\text { Adult* } \\
\text { Young Adult* } \\
\text { Student* }\end{array}$ \\
\hline
\end{tabular}




\begin{tabular}{|l|l|l|l|l|}
\hline & $\begin{array}{l}\text { Self-Efficac* } \\
\text { Resilienc* }\end{array}$ & $\begin{array}{l}\text { intervention* } \\
\text { Intervention* }\end{array}$ & \\
\hline $\begin{array}{l}\text { MeSH } \\
\text { subheadings }\end{array}$ & $\begin{array}{l}\text { Social Capital/ } \\
\text { Human Capital/ } \\
\text { exp Organizational } \\
\text { Behavior } \\
\text { Positive } \\
\text { Psychology/ or exp } \\
\text { "Resilience } \\
\text { (Psychological)"/ }\end{array}$ & $\begin{array}{l}\text { exp Cognitive Behavior } \\
\text { Therapy/ or exp } \\
\text { Intervention/ or exp } \\
\text { Psychotherapy/ or exp } \\
\text { Treatment Effectiveness } \\
\text { Evaluation/ }\end{array}$ & $\begin{array}{l}\text { exp procrastination/ } \\
\text { or exp productivity/ } \\
\text { or exp achievement/ } \\
\text { or exp performance/ } \\
\text { exp occuational } \\
\text { stress/ or exp "quality } \\
\text { of work life"/ } \\
\text { Time Management } \\
\text { exp motivation/ }\end{array}$ & N/A \\
\hline
\end{tabular}

\section{Appendix 2:}

Grey Literature Searches - January 31, 2021

January 31, 2021

\begin{tabular}{|l|l|}
\hline Database & Search \\
\hline Frontiers & (Psychological Capital) \\
\hline $\begin{array}{l}\text { Web of Science } \\
\text { Citation Index }\end{array}$ & $\begin{array}{l}\text { (Psychological Capital OR PsyCap OR hope OR optimis* OR } \\
\text { self-efficac* OR resilienc*) AND (Psychological capital intervention* } \\
\text { OR PsyCap intervention* OR Virtual intervention* OR Web-based } \\
\text { intervention* OR Intervention*) AND (Adult* OR Young Adult* OR } \\
\text { Student*) AND (Productiv* OR Performance OR Procrast* OR } \\
\text { efficienc* OR motivation) }\end{array}$ \\
\hline $\begin{array}{l}\text { Google scholar } \\
\text { preliminary search } \\
\text { string }\end{array}$ & $\begin{array}{l}\text { ("Psychological capital" OR "PsyCap") AND ("Psychological capital } \\
\text { intervention" OR "PsyCap intervention" OR "Virtual intervention" OR } \\
\text { "Web-based intervention" OR "Intervention") AND ("Productivity" OR } \\
\text { "Performance" OR "Procrastination" OR "efficiency" OR "motivation") } \\
\text { filetype:pdf }\end{array}$ \\
\hline $\begin{array}{l}\text { American } \\
\text { Psychological } \\
\text { Association (APA) }\end{array}$ & \begin{tabular}{l} 
(Psychological Capital) \\
\hline ClinicalTrials.gov
\end{tabular} \\
\hline
\end{tabular}




\section{Appendix 3: Study Characteristics Table}

\begin{tabular}{|c|c|c|c|c|c|}
\hline & Country & $\begin{array}{c}\text { Study design, duration, and } \\
\text { participants }\end{array}$ & Type of Data & Results & $\begin{array}{l}\text { Quality: } \\
\text { Design/score }\end{array}$ \\
\hline Luthans $2006[\mathrm{x}]$ & United States & $\begin{array}{l}\text { Participants were assigned to } \\
\text { a 1-3 hour micro-intervention }\end{array}$ & $\begin{array}{l}\text { Qualitative } \\
\text { interviews }\end{array}$ & $\begin{array}{l}\text { PsyCap Intervention (PCI) is shown to have } \\
\text { preliminary support for not only increasing } \\
\text { participants' PsyCap, but also financial } \\
\text { impact and high return on investment. }\end{array}$ & $1 / * *$ \\
\hline $\begin{array}{l}\text { Ruderman } 2015(\mathrm{x}) \\
\text { Developing leadership by } \\
\text { building psychological } \\
\text { capital }\end{array}$ & United States & $\begin{array}{l}\text { Experimental design: } \\
\text { assessment } 1 \text { day prior and } 5 \\
\text { days after intervention, } \\
50 \text {-min intervention }\end{array}$ & & $\begin{array}{l}\text { Leadership Development Program increases } \\
\text { psychological capital, prior experience with } \\
\text { mindfulness is related to psychological } \\
\text { capital. }\end{array}$ & $1 / * *$ \\
\hline $\begin{array}{l}\text { Black } 2020 \text { (Dec 7) The } \\
\text { missing HEROs: the } \\
\text { absence of, and need for, } \\
\text { PsyCap research of online } \\
\text { university students }\end{array}$ & UK & $\begin{array}{l}\text { Qualitative study (3-day } \\
\text { research performed), } \\
\text { systematic review, narrative } \\
\text { research }(n=69)\end{array}$ & $\begin{array}{l}\text { Foundational } \\
\text { literature in psycap, } \\
\text { existing studies } \\
\text { available online }\end{array}$ & $\begin{array}{l}\text { PsyCap and its elements manifested in } \\
\text { outcomes of higher academic performance } \\
\text { for online students similar to its } \\
\text { manifestation of higher performance in a } \\
\text { workplace setting. }\end{array}$ & $1 / * * *$ \\
\hline $\begin{array}{l}\text { Kalman } 2017 \text { (x) } \\
\text { Revitalizing the HERO } \\
\text { within Teachers: An } \\
\text { Analysis of the Effects of } \\
\text { the PsyCap Development } \\
\text { Training }\end{array}$ & Turkey & $\begin{array}{l}\text { Case study design, 2-month } \\
\text { weekly intervention with } \\
\text { middle school teachers } \\
(\mathrm{n}=12)\end{array}$ & In-depth interviews & $\begin{array}{l}\text { Implemented training intervention was } \\
\text { effective both for teachers' personal and } \\
\text { professional lives and development. The } \\
\text { intervention's effects on the hope dimension } \\
\text { of PsyCap were raising awareness about the } \\
\text { shortcomings in goal-setting, feeling more } \\
\text { enthusiastic for eliminating personal deficits } \\
\text { in goal setting and feeling more hopeful. }\end{array}$ & $1 / * * *$ \\
\hline $\begin{array}{l}\text { Li } 2018 \text { (July) Research on } \\
\text { Psychological Capital } \\
\text { Intervention of College } \\
\text { Students }\end{array}$ & China & $\begin{array}{l}\text { Qualitative description } \\
\text { design, 1-month } \\
\text { investigation, with university } \\
\text { students }(\mathrm{N}=340)\end{array}$ & Questionnaires & $\begin{array}{l}\text { The positive influence intervention on the } \\
\text { psychological capital level of university } \\
\text { students starts from two aspects: One is the } \\
\text { optimization of external environment, and } \\
\text { the other is the design of corresponding } \\
\text { simulation experiment courses for four } \\
\text { dimensions. }\end{array}$ & $1 / * * *$ \\
\hline $\begin{array}{l}\text { Waite } 2004(\mathrm{x}) \text { Determining } \\
\text { the efficacy of resiliency } \\
\text { training in the work site. }\end{array}$ & USA & $\begin{array}{l}\text { Experimental design: five } \\
\text { 8-hour interventions } \\
\text { implemented at a government } \\
\text { organization's facility. } \\
(\mathrm{n}=150)\end{array}$ & Survey & $\begin{array}{l}\text { The results of the study support the efficacy } \\
\text { of the PRRR training as implemented in the } \\
\text { work site. Intervention has positive effects } \\
\text { on resilience/reintegration, selected resilient } \\
\text { qualities (self-esteem, locus of control, } \\
\text { purpose in life, and interpersonal relations). }\end{array}$ & $1 / * * *$ \\
\hline $\begin{array}{l}\text { Rizzato } 2014[x] \text { A brief } \\
\text { online loving-kindness } \\
\text { meditation intervention; } \\
\text { effects on optimism and } \\
\text { affect }\end{array}$ & Ireland & $\begin{array}{l}\text { Mixed-method design; } \\
15 \text {-day-trial following a } \\
5 \text {-day-pilot testing phase at a } \\
\text { care-hospital among formal } \\
\text { caregivers ( } \mathrm{n}=70) . \\
62 \text { internet users ( } 1 \text { extreme } \\
\text { outlier), } 26 \text { male and } 35 \\
\text { female, aged } 24-47 \\
\text { (experimental group) and } \\
25-44 \text { (control group). }\end{array}$ & $\begin{array}{l}\text { Observations }(12 \\
\mathrm{h}) \text {, questionnaires } \\
\text { and in-depths } \\
\text { interviews }(\mathrm{n}=10)\end{array}$ & $\begin{array}{l}\text { Plausible positive directional trend in } \\
\text { Positive Affect scores (from PANAS Score } \\
30 \text { in Survey } 1 \text { to }>32.50 \text { in Survey } 2 \text { ), but } \\
\text { no significant improvements when } \\
\text { compared to the control group. No } \\
\text { hypothesis supported by findings. }\end{array}$ & $1 / * * * *$ \\
\hline $\begin{array}{l}\text { Houston } 2017(\mathrm{x}) \\
\text { Randomized controlled trial } \\
\text { of the Resilience and Coping } \\
\text { Intervention (RCI) with } \\
\text { undergraduate university } \\
\text { students }\end{array}$ & USA & $\begin{array}{l}\text { Random control study, pre } \\
\text { and post-intervention } \\
\text { assessment, three } 45 \text {-minute } \\
\text { interventions over } 3 \text { weeks, } \\
\text { with college students ( } \mathrm{n}= \\
129)\end{array}$ & Questionnaires & $\begin{array}{l}\text { This study found preliminary evidence that } \\
\text { RCI (Resilience and Coping Intervention) is } \\
\text { an effective resilience intervention for use } \\
\text { with college students. }\end{array}$ & $2 / * *$ \\
\hline
\end{tabular}




\begin{tabular}{|c|c|c|c|c|c|}
\hline $\begin{array}{l}\text { Stratman } 2019 \text { (Feb 21) Can } \\
\text { positivity promote safety? } \\
\text { Psychological capital } \\
\text { development combats } \\
\text { cynicism and unsafe } \\
\text { behavior }\end{array}$ & USA & $\begin{array}{l}\text { Experimental design, } \\
\text { Exploratory intervention } \\
\text { (90-min) followed by a } \\
\text { goal-setting exercise. } \\
\text { Post-intervention } \\
\text { measurement occurred } 2 \\
\text { months later. }(\mathrm{n}=130)\end{array}$ & $\begin{array}{l}\text { Psychological } \\
\text { Capital } \\
\text { Questionnaire, } \\
\text { surveys }\end{array}$ & $\begin{array}{l}\text { PsyCap development is an effective } \\
\text { approach in increasing positivity, reducing } \\
\text { cynicism and unsafe behaviors. }\end{array}$ & $2 / * *$ \\
\hline $\begin{array}{l}\text { Barry } 2018[\mathrm{x}] \text { A } \\
\text { randomized controlled trial } \\
\text { of the effects of mindfulness } \\
\text { practice on doctoral } \\
\text { candidate psychological } \\
\text { status }\end{array}$ & Australia & $\begin{array}{l}\text { Randomized control trial; } \\
\text { Participants were randomly } \\
\text { assigned to a control group or } \\
\text { a } 30 \text {-minute mindfulness } \\
\text { practice intervention using } \\
\text { audio CD for } 8 \text { weeks and } \\
\text { were assessed pre-and } \\
\text { post-intervention; } \\
\text { Participants were doctoral } \\
\text { candidates. }(n=72)\end{array}$ & $\begin{array}{l}\text { Questionnaires and } \\
\text { qualitative } \\
\text { questions }\end{array}$ & $\begin{array}{l}\text { Intervention group was significantly less } \\
\text { depressed, although not clinically } \\
\text { significant, and had increased self-efficacy, } \\
\text { hope, resilience and total PsyCap compared } \\
\text { to controls. }\end{array}$ & $2 / * * *$ \\
\hline $\begin{array}{l}\text { Feldman } 2011 \text { (Aug 31) Can } \\
\text { Hope be Changed in } 90 \\
\text { Minutes? Testing the } \\
\text { Efficacy of a Single-Session } \\
\text { Goal-Pursuit Intervention } \\
\text { for College Students }\end{array}$ & USA & $\begin{array}{l}\text { Exploratory intervention } \\
(90-\text { min }), \text { followed by a } \\
\text { post-test randomized } \\
\text { controlled trial testing. } \\
\text { Participants: } 96 \text { college } \\
\text { students from a university of } \\
\text { Northern California }(\mathrm{n}=96)\end{array}$ & $\begin{array}{l}\text { Focus groups (6-8 } \\
\text { students), surveys, } \\
\text { Goal-Specific Hope } \\
\text { Scale, Purpose in } \\
\text { Life Test }\end{array}$ & $\begin{array}{l}\text { A single-session intervention can increase } \\
\text { hope in the short term as well as lead to } \\
\text { greater levels of goal progress as much as a } \\
\text { month later. }\end{array}$ & $2 / * * *$ \\
\hline $\begin{array}{l}\text { Hangrove } 2012[\mathrm{x}] \\
\text { Antecedents and outcomes } \\
\text { associated with the } \\
\text { individual stress response }\end{array}$ & United States & $\begin{array}{l}\text { Randomized controlled field } \\
\text { experiment; Participants } \\
\text { were assigned to a } \\
\text { Psychological Capital } \\
\text { Training group group or } \\
\text { waitlist group and asset at } \\
\text { pre- and post-test; } \\
\text { Participants were employees } \\
\text { of a company. }(\mathrm{n}=110)\end{array}$ & Online surveys & $\begin{array}{l}\text { No significant increase between pre- and } \\
\text { post-intervention PsyCap scores, Psycap } \\
\text { was not a moderator of relationship between } \\
\text { stressors and stress response; Employees of } \\
\text { managers that participated in the PsyCap } \\
\text { intervention experienced an increase in their } \\
\text { own PsyCap levels. }\end{array}$ & $2 / * * *$ \\
\hline $\begin{array}{l}\text { Kosenkranius } 2020(\mathrm{x}) \text { The } \\
\text { design and development of a } \\
\text { hybrid off-job crafting } \\
\text { intervention to enhance } \\
\text { needs satisfaction, } \\
\text { well-being and } \\
\text { performance: a study } \\
\text { protocol for a randomized } \\
\text { controlled trial }\end{array}$ & Finland & $\begin{array}{l}\text { Random controlled trial, } \\
\text { assessed } 2 \text { weeks pre-test, } \\
\text { during } 4 \text {-week intervention } \\
\text { and } 2 \text { follow-ups after } \\
\text { intervention }(2 \& 6 \text { weeks }) \\
\text { with Finnish knowledge } \\
\text { workers }(n=64)\end{array}$ & $\begin{array}{l}\text { Weekly online } \\
\text { questionnaires, } \\
\text { focus groups }\end{array}$ & $\begin{array}{l}\text { Participation in the trainings, following an } \\
\text { individual off-job crafting plan, and using } \\
\text { the smartphone app a brief and accessible } \\
\text { way for employees which can contribute to } \\
\text { enhance psychological needs satisfaction, } \\
\text { well-being and performance in different life } \\
\text { domains. }\end{array}$ & $2 / * * *$ \\
\hline $\begin{array}{l}\text { Luthans } 2013 \text { [x] Building } \\
\text { the Leaders of Tomorrow: } \\
\text { The } \\
\text { Development of Academic } \\
\text { Psychological } \\
\text { Capital }\end{array}$ & USA & $\begin{array}{l}\text { Experimental design; 2-hour } \\
\text { training intervention } \\
\text { (exercises/group discussions) } \\
(\mathrm{n}=214)\end{array}$ & $\begin{array}{l}\text { Questionnaires } \\
\text { (Self-report) }\end{array}$ & $\begin{array}{l}\text { Academic PsyCap of business students can } \\
\text { be positively affected by short training } \\
\text { interventions such as the PCI. Students must } \\
\text { continually } \\
\text { work to proactively develop their Academic } \\
\text { PsyCap in order } \\
\text { to create a lasting effect for overcoming } \\
\text { barriers to academic } \\
\text { success. }\end{array}$ & $2 / * * *$ \\
\hline $\begin{array}{l}\text { Williams } 2017 \text { (Jan 19) The } \\
\text { Role and Reprocessing of } \\
\text { Attitudes in Fostering } \\
\text { Employee Work Happiness: } \\
\text { An Intervention Study }\end{array}$ & Australia & $\begin{array}{l}\text { Quasi-experimental design: } \\
\text { pre-test, intervention (3-day), } \\
\text { 8-week post-test, with school } \\
\text { staff }(\mathrm{n}=69)\end{array}$ & $\begin{array}{l}\text { Questionnaires, } \\
\text { online surveys } \\
\text { (available for } 10 \\
\text { days) }\end{array}$ & $\begin{array}{l}\text { This study highlights the merit in } \\
\text { understanding non-conscious processes such } \\
\text { as implicit attitudes in wellbeing research, } \\
\text { and their value to positive psychology } \\
\text { interventions measurement programs. }\end{array}$ & $2 / * * *$ \\
\hline
\end{tabular}




\begin{tabular}{|c|c|c|c|c|c|}
\hline $\begin{array}{l}\text { Zhang } 2014[\mathrm{x}] \text { A Structured } \\
\text { Reading Materials-Based } \\
\text { Intervention Program to } \\
\text { Develop the Psychological } \\
\text { Capital of Chinese } \\
\text { Employees }\end{array}$ & China & $\begin{array}{l}\text { Randomized controlled trial; } \\
\text { Participants were randomly } \\
\text { assigned to an Intervention } \\
\text { group based on } 30 \text {-min } \\
\text { structured reading material } \\
\text { and a control group and were } \\
\text { assessed pre-, } 2 \text { weeks post- } \\
\text { and } 3 \text { months } \\
\text { post-intervention; } \\
\text { Participants were Chinese } \\
\text { employees from } 5 \\
\text { companies. }(\mathrm{n}=234)\end{array}$ & $\begin{array}{l}\text { Quantitative } \\
\text { questionnaires }\end{array}$ & $\begin{array}{l}\text { Intervention group had significantly } \\
\text { improved overall PsyCap, its } 4 \text { components, } \\
\text { and job performance. Control group had no } \\
\text { significant change in PsyCap and job } \\
\text { performance. }\end{array}$ & $2 / * * *$ \\
\hline $\begin{array}{l}\text { Hodges } 2010[\mathrm{x}] \text { An } \\
\text { Experimental Study of the } \\
\text { Impact of Psychological } \\
\text { Capital on Performance, } \\
\text { Engagement, and the } \\
\text { Contagion Effect }\end{array}$ & USA & $\begin{array}{l}\text { Randomized controlled trial; } \\
\text { Participants were assigned to } \\
\text { a control group and a } \\
\text { 6-weeks long PsyCap } \\
\text { micro-intervention group and } \\
\text { assessed at pre- and } \\
\text { post-intervention; } \\
\text { Participants were employees } \\
\text { in financial services. }(\mathrm{n}=501)\end{array}$ & Surveys & $\begin{array}{l}\text { The PsyCap ratings for the control group } \\
\text { actually decreased during the same time } \\
\text { period, while the treatment group } \\
\text { experienced a slight increase. There was no } \\
\text { significant difference in PsyCap scores } \\
\text { between the control and treatment groups at } \\
\text { the pre-test, but the post-test ratings for the } \\
\text { treatment groups wre higher. }\end{array}$ & $2 / * * * *$ \\
\hline $\begin{array}{l}\text { Luthans } 2010(\mathrm{x}) \text { The } \\
\text { Development and Resulting } \\
\text { Performance } \\
\text { Impact of Positive } \\
\text { Psychological Capital }\end{array}$ & USA & $\begin{array}{l}\text { Random control-group } \\
\text { design, pilot test (advanced } \\
\text { management students) before } \\
\text { a 2-hour intervention, } \\
\text { followed by a 3-day } \\
\text { pre-intervention and 3-day } \\
\text { follow-up study, with } \\
\text { practicing managers }(\mathrm{n}=80)\end{array}$ & $\begin{array}{l}\text { Questionnaire } \\
\text { (24-item psycap } \\
\text { questionnaire } \\
\text { [PCQ], } \\
\text { self-assessment of } \\
\text { performance } \\
\text { outcomes) }\end{array}$ & $\begin{array}{l}\text { Short training interventions such as PCI not } \\
\text { only may be used to develop participants' } \\
\text { psychological capital, but can also lead to an } \\
\text { improvement in their on-the-job } \\
\text { performance. }\end{array}$ & $2 / * * * *$ \\
\hline $\begin{array}{l}\text { Peters } 2013 \text { (Jan 9) } \\
\text { Specificity of the Best } \\
\text { Possible Self intervention } \\
\text { for increasing optimism: } \\
\text { Comparison with a gratitude } \\
\text { intervention }\end{array}$ & Netherlands & $\begin{array}{l}\text { Experimental design: two } \\
1 \text {-week interventions, 1-week } \\
\text { follow up with participants } \\
\text { following university or } \\
\text { advanced professional } \\
\text { training }(\mathrm{n}=82)\end{array}$ & $\begin{array}{l} \\
\text { Questionnaires ( } \\
\text { Attributional Style } \\
\text { Questionnaire) }\end{array}$ & $\begin{array}{l}\text { The best possible self intervention is an } \\
\text { effective exercise if one aims to increase } \\
\text { optimism (One week of Best Possible Self } \\
\text { imagery led to significant } \\
\text { increases in both satisfaction with life and } \\
\text { optimism) }\end{array}$ & $2 / * * * *$ \\
\hline $\begin{array}{l}\text { Luthans } 2008(\mathrm{x}) \\
\text { Experimental Analysis of a } \\
\text { Web-Based Training } \\
\text { Intervention to Develop } \\
\text { Positive Psychological } \\
\text { Capital }\end{array}$ & USA & $\begin{array}{l}\text { Experimental design: pretest, } \\
\text { posttest control group, } \\
\text { web-based intervention ( } 2 \\
\text { hour) on wolking adults ( } \\
\text { manufacturing, service,sales, } \\
\text { and government) }(\mathrm{n}=364)\end{array}$ & $\begin{array}{l}\text { Surveys, } \\
\text { questionnaires, }\end{array}$ & $\begin{array}{l}\text { The investment and development in } \\
\text { psychological capital has the potential to } \\
\text { provide competitive advantage for } \\
\text { organizations through web based delivery, } \\
\text { an inexpensive, practical, and potentially } \\
\text { effective means. }\end{array}$ & $2 / * * * * *$ \\
\hline $\begin{array}{l}\text { McGonagle } 2020(\mathrm{x}) \\
\text { Coaching for Primary Care } \\
\text { Physician Well-Being: A } \\
\text { Randomized Trial and } \\
\text { Follow-Up Analysis }\end{array}$ & USA & $\begin{array}{l}\text { Randomized control trial } \\
\text { design: survey pre-test ( } 3 \\
\text { months), 3-month } \\
\text { intervention and post-test } \\
\text { survey ( } 3 \text { months later) of } \\
\text { early-mid-career physicians } \\
(\mathrm{n}=59)\end{array}$ & $\begin{array}{l}\text { Surveys (pre-test } \\
\text { post-test), phone } \\
\text { intervention }\end{array}$ & $\begin{array}{l}\text { Coaching is a helpful intervention for } \\
\text { improving PCP } \\
\text { burnout, engagement, and psychological } \\
\text { capital. Positive } \\
\text { psychology coaching fosters positive } \\
\text { emotion, resilience and } \\
\text { well-being by providing space and support } \\
\text { for client reflection, goal directed behavior, } \\
\text { and personal growth. }\end{array}$ & $2 / * * * * *$ \\
\hline
\end{tabular}




\begin{tabular}{|c|c|c|c|c|c|}
\hline $\begin{array}{l}\text { Peláez Zuberbuhler } 2020 \text { [x] } \\
\text { Coaching-Based Leadership } \\
\text { Intervention Program: A } \\
\text { Controlled Trial Study. }\end{array}$ & Spain & $\begin{array}{l}\text { Non-randomized controlled } \\
\text { trial; Executives and middle } \\
\text { managers }(\mathrm{N}=41) \text { from an } \\
\text { automotive sector company } \\
\text { in Spain assigned to a } \\
\text { waiting-list control group } \\
(\mathrm{n}=16) \text { and } 180 \text {-minute } \\
\text { weekly Coaching-based } \\
\text { leadership intervention } \\
\text { program ( } \mathrm{n}=25) \text {; Assessed } \\
\text { both groups pre-intervention, } \\
\text { post-intervention of the } \\
\text { experimental group and } \\
\text { pre-assessment for the } \\
\text { waiting-list group, } \\
\text { post-assessment for waiting } \\
\text { list group and } 4 \text { months } \\
\text { follow-up for both groups. }\end{array}$ & $\begin{array}{l}\text { Online } \\
\text { questionnaire with } \\
\text { quantitative } \\
\text { questionnaires for } \\
\text { coaching-based } \\
\text { leadership skills, } \\
\text { PsyCap, levels of } \\
\text { work engagement, } \\
\text { and in- and } \\
\text { extra-role } \\
\text { performance and } \\
\text { qualitative } \\
\text { open-ended } \\
\text { question. }\end{array}$ & $\begin{array}{l}\text { |l } \\
\text { Post-intervention group resulted in } \\
\text { significantly higher PsyCap scores }[\mathrm{t}(37)= \\
-3.65 \mathrm{p}<0.001, \mathrm{~d}=1.20] \text { but no significant } \\
\text { differences between pre-intervention scores } \\
\text { and after 4-month follow-up }[\mathrm{t}(34)=-0.94 \mathrm{p} \\
=0.35 ; \mathrm{ns}]\end{array}$ & $3 / *$ \\
\hline $\begin{array}{l}\text { Clauss } 2018[\mathrm{x}] \text { Promoting } \\
\text { personal resources and } \\
\text { reducing exhaustion through } \\
\text { positive work reflection } \\
\text { among caregivers. }\end{array}$ & Germany & $\begin{array}{l}\text { Non-randomized controlled } \\
\text { design; Caregivers from } \\
\text { nursing homes, retirement } \\
\text { homes, and mobile } \\
\text { care-giviing organizations } \\
\text { were assigned to an } \\
\text { intervention group where } \\
\text { they conducted exercising in } \\
\text { their working day for } 10 \text { days } \\
\text { ( } \mathrm{n}=46) \text { and a control group } \\
\text { ( } \mathrm{n}=48) \text {; Assessed pre-test, } 10 \\
\text { days post-test and two-weeks } \\
\text { follow-up. }(\mathrm{n}=97)\end{array}$ & $\begin{array}{l}\text { Quantitative } \\
\text { measures of } \\
\text { optimis, hope, } \\
\text { emotional } \\
\text { exhaustion, fatigue } \\
\text { and need for } \\
\text { recovery. }\end{array}$ & $\begin{array}{l}\text { Intervention had significant effects on } \\
\text { emotional exhaustion and fatigue, } \\
\text { confirming a short daily positive (work) } \\
\text { reflection session helps to prevent a decrease } \\
\text { of energy and supports recovery from } \\
\text { negative arousal. Hope and optimism did not } \\
\text { increase for the intervention group when } \\
\text { comparing it with the control group }\end{array}$ & 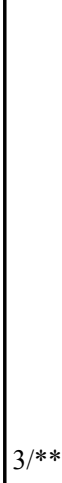 \\
\hline $\begin{array}{l}\text { Corbu } 2021[\mathrm{x}] \text { Positive } \\
\text { Psychology Micro-Coaching } \\
\text { Intervention: Effects on } \\
\text { Psychological Capital and } \\
\text { Goal-Related Self-Efficacy }\end{array}$ & Spain & $\begin{array}{l}\text { Non-randomized controlled } \\
\text { trial; Employees with } \\
\text { technical and engineering } \\
\text { positions ( } \mathrm{N}=60) \text { from an } \\
\text { automotive sector company } \\
\text { in Spain assigned to a } \\
\text { waiting-list control group } \\
(\mathrm{n}=25) \text { and a } 190 \text {-minute } \\
\text { biweekly strengths-based } \\
\text { micro-coaching program } \\
(\mathrm{n}=35) \text {; Assessed both } \\
\text { groups pre-intervention, } \\
\text { post-intervention of the } \\
\text { experimental group and } \\
\text { pre-assessment for the } \\
\text { waiting-list group, } \\
\text { post-assessment for waiting } \\
\text { list group and } 4 \text { months } \\
\text { follow-up for both groups. }\end{array}$ & $\begin{array}{l}\text { Online } \\
\text { questionnaire with } \\
\text { quantitative } \\
\text { questionnaires for } \\
\text { goal-related } \\
\text { self-efficacy, goal } \\
\text { attainment and } \\
\text { PsyCap. }\end{array}$ & $\begin{array}{l}\text { Significantly higher levels of PsyCap at Post } \\
{[\mathrm{t}(53)=-5.22 \mathrm{p}<0.001, \mathrm{~d}=1.42], \text { and FUP }} \\
{[\mathrm{t}(46)=-5.65 \mathrm{p}<0.001, \mathrm{~d}=1.66]} \\
\text { compared to Pre time }\end{array}$ & $\mid$ \\
\hline $\begin{array}{l}\text { Fu } 2020[\mathrm{x}] \text { Promoting } \\
\text { effect of traditional music } \\
\text { education on the } \\
\text { psychological capital of } \\
\text { college students }\end{array}$ & China & $\begin{array}{l}\text { Non-randomized controlled } \\
\text { trial; college students were } \\
\text { assigned to an intervention } \\
\text { program with weekly } 1.5 \\
\text { hour sessions for } 6 \text { weeks } \\
(\mathrm{n}=23) \text { and control group } \\
(\mathrm{n}=23) \text { and were assessed } \\
\text { pre-, and post-intervention. } \\
(\mathrm{N}=46)\end{array}$ & $\begin{array}{l}\text { Quantitative } \\
\text { measures of Psycap }\end{array}$ & $\begin{array}{l}\text { Significant differences between the pretest } \\
\text { scores and the } \\
\text { post-test scores of the experimental group, } \\
\text { indicating that traditional music can play a } \\
\text { positive role in improving the psychological } \\
\text { capital level of college students. }\end{array}$ & $3 / * *$ \\
\hline
\end{tabular}




\begin{tabular}{|c|c|c|c|c|c|}
\hline $\begin{array}{l}\text { Geremias } 2020[\mathrm{x}] \\
\text { Enhancing Internal Learning } \\
\text { in Teams: The Role of } \\
\text { Network Centrality and } \\
\text { Psychological Capital of } \\
\text { Undergraduate Students }\end{array}$ & Spain & $\begin{array}{l}\text { Cross-sectional study; } \\
\text { Undergraduate students from } \\
\text { three higher education } \\
\text { institutions completed an } \\
\text { online questionnaire } 4 \\
\text { months after classes began } \\
\text { (n=480), } 54 \% \text { of participants } \\
\text { were men, average age was } \\
24 \text { years ( } \mathrm{SD}=5.94) .61 \% \\
\text { were in first year, } 21 \% \text { in } \\
\text { second year, } 11 \% \text { from third } \\
\text { year and } 7 \% \text { from fourth } \\
\text { year. }\end{array}$ & $\begin{array}{l}\text { Questionnaire } \\
\text { distributed in clas } \\
\text { with qualitative and } \\
\text { quantitative } \\
\text { measures for } \\
\text { network centrality } \\
\text { and quantitative } \\
\text { measures for } \\
\text { PsyCap and } \\
\text { internal learning in } \\
\text { teams. }\end{array}$ & $\begin{array}{l}\text { Network centrality a positively influenced } \\
\text { internal learning in teams }(\beta=0.085 ; p= \\
0.009) \text { and network centrality positively } \\
\text { influenced PsyCap ( } \beta=0.173 ; p=0.004) \text {. } \\
\text { PsyCap is significantly and positively } \\
\text { related to internal learning in teams ( } \beta= \\
0.325 ; \rho<0.001) \text {.nPsyCap fully mediates } \\
\text { the relationship between network centrality } \\
\text { and internal learning in teams (indirect } \\
\text { effect }=0.058 ; 90 \% \text { CI limits to } 0.030 \text { and } \\
0.104)\end{array}$ & (1) \\
\hline $\begin{array}{l}\text { Goertzen } 2015 \text { (July 13) } \\
\text { Development of } \\
\text { psychological capital in an } \\
\text { academic-based leadership } \\
\text { education program }\end{array}$ & USA & $\begin{array}{l}\text { Cohort study, surveyed at } \\
\text { beginning, during and end of } \\
\text { intervention, on } \\
\text { undergraduate students ( } \mathrm{n}= \\
1212)\end{array}$ & $\begin{array}{l}\text { Self-report, } \\
\text { web-based surveys }\end{array}$ & $\begin{array}{l}\text { Results indicated PsyCap capacities } \\
\text { (self-efficacy, optimism, hope and } \\
\text { resiliency) may be impacted through } \\
\text { leadership training and that online delivery } \\
\text { appeared to have the greatest impact on } \\
\text { student PsyCap development. }\end{array}$ & $3 / * *$ \\
\hline $\begin{array}{l}\text { Zhao } 2019[\mathrm{x}] \text { Promoting } \\
\text { effect of psychological } \\
\text { capital construction of } \\
\text { college students on English } \\
\text { teaching }\end{array}$ & China & $\begin{array}{l}\text { Non-randomized controlled } \\
\text { trial; college students with } \\
\text { low psychological capital } \\
\text { were assigned to an } \\
\text { intervention program }(\mathrm{n}=51) \\
\text { and control group }(\mathrm{n}=50) \text { and } \\
\text { were assessed pre-, } 2 \text { months } \\
\text { post- and } 4 \text { months } \\
\text { post-intervention. }(\mathrm{N}=101)\end{array}$ & $\begin{array}{l}\text { Quantitative } \\
\text { measures of } \\
\text { PsyCap and } \\
\text { English learning } \\
\text { efficacy }\end{array}$ & $\begin{array}{l}\text { The psychological capital intervention } \\
\text { model (PCI) can effectively improve the } \\
\text { psychological capital level and English } \\
\text { learning } \\
\text { efficacy of college students. A positive } \\
\text { correlation between college students' } \\
\text { psychological capital and English learning } \\
\text { efficacy was found }\end{array}$ & $3 / * *$ \\
\hline $\begin{array}{l}\text { Avey } 2008 \text { (x) The } \\
\text { Addictive Value of Positive } \\
\text { Psychological Capital in } \\
\text { Psychological Capital in } \\
\text { Predicting Work Attitudes } \\
\text { and Behaviors }\end{array}$ & USA & $\begin{array}{l}\text { Cross-sectional research } \\
\text { design, } 2 \text { sessions separated } \\
\text { by 7-14 days }(\mathrm{n}=336)\end{array}$ & $\begin{array}{l}\text { Questionnaire } \\
\text { (PsyCap } \\
\text { Questionnaire } \\
\text {-PCQ), survey }\end{array}$ & $\begin{array}{l}\text { Those who are higher in PsyCap not only } \\
\text { engage in more desirable behaviors (OCBs), } \\
\text { but also fewer undesirable } \\
\text { counterproductive work behaviors (CWBs). }\end{array}$ & $3 / * * *$ \\
\hline $\begin{array}{l}\text { Avey } 2010[\mathrm{x}] \text { Impact of } \\
\text { Positive Psychological } \\
\text { Capital on Employee } \\
\text { chological Capital on } \\
\text { Employee Well-Being } \\
\text { Over Time }\end{array}$ & United States & $\begin{array}{l}\text { Cross-sectional study; } \\
\text { Working adults completed a } \\
30 \text { minute survey at } 2 \text { time } \\
\text { points } 3 \text { weeks apart } \\
\text { assessing employees attitude } \\
\text { and behaviours and } \\
\text { organizational performance } \\
(\mathrm{n}=280) \text {; Average age of } 31.7 \\
(\mathrm{SD}-13.67), 86 \% \text { white, } 51 \% \\
\text { male. } 70 \% \text { had a high school } \\
\text { diploma as the highest level } \\
\text { of education. Average of } 10.5 \\
\text { years of work experience } \\
(\mathrm{SD}=11.79)\end{array}$ & $\begin{array}{l}\text { Online } \\
\text { questionnaire with } \\
\text { quantitative } \\
\text { questionnaires for } \\
\text { PsyCap and } \\
\text { psychological } \\
\text { well-being. }\end{array}$ & $\begin{array}{l}\text { PsyCap was significantly correlated with } \\
\text { both measures of PWB at both time poinnts. } \\
\text { The relationship was stronger and more } \\
\text { stable for the Index of PWB }(\mathrm{r}=.47, \mathrm{p}< \\
.01), \text { than for the GHQ respectively }(\mathrm{r}=.24, \\
\mathrm{p}<.01 ; \mathrm{r}=.27, \mathrm{p}<.01)\end{array}$ & $3 / * * *$ \\
\hline $\begin{array}{l}\text { Breso' } 2010(\mathrm{x}) \text { Can a } \\
\text { self-efficacy-based } \\
\text { intervention decrease } \\
\text { burnout,increase } \\
\text { engagement, and enhance } \\
\text { performance? A } \\
\text { quasi-experimental study }\end{array}$ & Spain & $\begin{array}{l}\text { Quasi-experimental study; } \\
\text { exploratory intervention (4 } \\
\text { 2-hour one-one sessions) } \\
\text { with students in various } \\
\text { departments of the university. } \\
(\mathrm{n}=71)\end{array}$ & $\begin{array}{l}\text { Questionnaires, } \\
\text { student surveys }\end{array}$ & $\begin{array}{l}\text { Self-efficacy-based intervention has positive } \\
\text { effects on students' well-being and } \\
\text { performance, one-on-one } \\
\text { cognitive-behavioral sessions proved } \\
\text { effective in improving both engagement and } \\
\text { performance. }\end{array}$ & $3 / * * *$ \\
\hline
\end{tabular}




\begin{tabular}{|c|c|c|c|c|c|}
\hline $\begin{array}{l}\text { Cenciotti } 2016[\mathrm{x}] \\
\text { Psychological Capital and } \\
\text { Career Success Over Time: } \\
\text { The Mediating Role of Job } \\
\text { Crafting }\end{array}$ & Italy & $\begin{array}{l}\text { Prospective cohort; } \\
\text { Employees from a service } \\
\text { organization worked as } \\
\text { middle managers completed } \\
\text { questionnaires over } 2 \text { years. } \\
(\mathrm{n}=349)\end{array}$ & $\begin{array}{l}\text { Quantitative } \\
\text { measures of } \\
\text { PsyCap, job } \\
\text { crafting, job } \\
\text { satisfaction and } \\
\text { hierarchical level. }\end{array}$ & $\begin{array}{l}\text { PsyCap is a significant predictor of job } \\
\text { crafting over time; positive and reciprocal } \\
\text { longitudinal prediction of PsyCap by job } \\
\text { crafting }\end{array}$ & $3 / * * *$ \\
\hline $\begin{array}{l}\text { Corby } 2021[\mathrm{x}] \text { Positive } \\
\text { Psychology Micro-Coaching } \\
\text { Intervention: Effects on } \\
\text { Psychological Capital and } \\
\text { Goal-Related Self-Efficacy }\end{array}$ & Spain & $\begin{array}{l}\text { Controlled trial; } \\
\text { Non-executive employees } \\
\text { were assigned to a Positive } \\
\text { Psychological } \\
\text { Micro-Coaching program } \\
(\mathrm{n}=35) \text { over } 5 \text { weeks and a } \\
\text { waiting-list control group } \\
(\mathrm{n}=25) \text { from an automotive } \\
\text { industry company and were } \\
\text { assessed at pre, post and } \\
\text { 4-month follow up. }(\mathrm{n}=60)\end{array}$ & $\begin{array}{l} \\
\text { Quantitative } \\
\text { measures of } \\
\text { psychological } \\
\text { capital, goal-related } \\
\text { self efficacy and } \\
\text { goal attainment }\end{array}$ & $\begin{array}{l}\text { psychological capital increased significantly } \\
\text { at post and follow-up times compared to } \\
\text { baseline levels. Goal-related self-efficacy } \\
\text { predicted goal attainment during the } \\
\text { micro-coaching process. Short-term positive } \\
\text { psychological coaching is a valuable method } \\
\text { of developing personal resources }\end{array}$ & $3 / * * *$ \\
\hline $\begin{array}{l}\text { Ertosun } 2015[\mathrm{x}] \text { Positive } \\
\text { Psychological Capital } \\
\text { Development: A Field Study } \\
\text { by the Solomon Four Group } \\
\text { Design }\end{array}$ & Turkey & $\begin{array}{l}\text { Field study; Management } \\
\text { students were assigned to a } 2 \\
\text { hour-long training program } \\
\text { and were assessed pre and } 10 \\
\text { days post-test }(n=156)\end{array}$ & $\begin{array}{l}\text { Quantitative } \\
\text { measures of Psycap } \\
\text { pre-and post-test }\end{array}$ & $\begin{array}{l}\text { A significant difference was found between } \\
\text { intervention groups pre and post } \\
\text { intervention. No significant differences were } \\
\text { found for other control groups. }\end{array}$ & $3 / * * *$ \\
\hline $\begin{array}{l}\text { Gergiou } 2019 \text { (x) The } \\
\text { Impact of a Training } \\
\text { Intervention Developing } \\
\text { Psychological Capital on } \\
\text { Job Search Success }\end{array}$ & Greece & $\begin{array}{l}\text { Longitudinal } \\
\text { quasi-experimental design, } \\
\text { self-assessment before, } \\
\text { immediately after and } 3 \\
\text { months after two 3-hour } \\
\text { intervention, with job-seekers } \\
\text { [n=220 (treatment group) } \\
n=447 \text { (control group)] }\end{array}$ & $\begin{array}{l}\text { Questionnaires } \\
\text { (demographics, } \\
\text { PsyCap, job-search } \\
\text { behaviour), surveys }\end{array}$ & $\begin{array}{l}\text { Those who received the PsyCap training } \\
\text { (treatment group) demonstrated higher } \\
\text { levels of job search behavior and obtained } \\
\text { employment at a higher rate, } 3 \text { months } \\
\text { following the intervention, compared to the } \\
\text { control group. }\end{array}$ & $3 / * * *$ \\
\hline $\begin{array}{l}\text { Gooty } 2009[\mathrm{x}] \text { In the Eyes } \\
\text { of the Beholder: } \\
\text { Transformational } \\
\text { Leadership, Positive } \\
\text { Psychological Capital, and } \\
\text { Performance }\end{array}$ & United States & $\begin{array}{l}\text { Prospective cohort study; } \\
\text { Marching band at a } \\
\text { midwestern university } \\
\text { (n=190) rated new band } \\
\text { director's transformational } \\
\text { research and their own } \\
\text { PsyCap. } 2 \text { weeks after survey } \\
\text { completion, the band } \\
\text { director's staff and assistants } \\
\text { rated in-role performance, } \\
\text { OCBI and OCBO; } 75 \% \text { of } \\
\text { participants of were male, } \\
\text { average age of } 25.3 \text { years, }\end{array}$ & $\begin{array}{l}\text { Quantitative } \\
\text { measures of } \\
\text { transformational } \\
\text { leadership, PsyCap } \\
\text { and performacne } \\
\text { outcomes. }\end{array}$ & $\begin{array}{l}\text { Followers' perceptions of trans-formational } \\
\text { leadership were significantly and positively } \\
\text { related to PsyCap. PsyCap was sig-nificantly } \\
\text { and positively related to in-role } \\
\text { performance, OCBI (organizational } \\
\text { citizenship behavior directed toward } \\
\text { individuals), and OCBO ( OCBO } \\
\text { organizational citizenship behavior directed } \\
\text { toward the organization). Followers' } \\
\text { perceptions of trans-formational leadership } \\
\text { to have significant indirect effects (via } \\
\text { PsyCap) on in-role performance } \\
\text { (stan-dardized estimate }=.77, \mathrm{p}<.05 \text { ), } \\
\text { OCBI (standardized estimate }=.60, \mathrm{p}<.05 \text { ), } \\
\text { and OCBO (standardized estimate }=.57, \mathrm{p}< \\
.05 \text { ) }\end{array}$ & $3 / * * *$ \\
\hline $\begin{array}{l}\text { Hulshof } 2019[\mathrm{x}] \text { A job } \\
\text { search demands-resources } \\
\text { intervention among the } \\
\text { unemployed: Effects on } \\
\text { well-being, job search } \\
\text { behavior and reemployment } \\
\text { chances }\end{array}$ & Netherlands & $\begin{array}{l}\text { Non-randomized controlled } \\
\text { trial; Participants were } \\
\text { assigned to a 3-day training } \\
\text { intervention or waiting-list } \\
\text { control group and assessed } \\
\text { before, immediately after and } \\
\text { 6-months following the } \\
\text { intervention; Participants } \\
\text { were unemployed individuals }\end{array}$ & $\begin{array}{l}\text { Qualitative } \\
\text { interviews (N=19) } \\
\text { and qualitative } \\
\text { reflections }\end{array}$ & $\begin{array}{l}\text { Reemployment, crafting and psycap } \\
\text { intervention significantly improved job } \\
\text { search behaviour and goal setting, but no } \\
\text { significant impact on reemployment status } \\
\text { after } 6 \text { months. }\end{array}$ & $3 / * * *$ \\
\hline
\end{tabular}




\begin{tabular}{|c|c|c|c|c|c|}
\hline & & $\begin{array}{l}\text { from a reemployment } \\
\text { agency. }(\mathrm{N}=163)\end{array}$ & & & \\
\hline $\begin{array}{l}\text { Liang } 2018 \text { (Dec 5) The } \\
\text { Psychological Capital of } \\
\text { Left-Behind University } \\
\text { Students: A Description and } \\
\text { Intervention Study From } \\
\text { China }\end{array}$ & China & $\begin{array}{l}\text { Experimental design: } \\
\text { pretest-posttest score of } \\
\text { psycap scale, once-weekly } \\
\text { counseling }(1.5 \mathrm{~h}) \text { for } 8 \\
\text { weeks, with university } \\
\text { students in Sichuan } \\
\text { University (China) } \\
\\
n=726 \text { ( } 281 \text { left behind, } 445 \\
\text { no left-behind experience) }\end{array}$ & $\begin{array}{l} \\
\text { Questionnaires } \\
\text { (mix of quantitative } \\
\text { and open-ended } \\
\text { questions_ }\end{array}$ & $\begin{array}{l}\text { gender, grade, only child status, student } \\
\text { leadership experience, reunion frequency } \\
\text { with parents, and the relationship with } \\
\text { guardians significantly influence the } \\
\text { psychological capital of USWL (University } \\
\text { students with left-behind experience); group } \\
\text { intervention based on the theory of PCI } \\
\text { (Psychological Capital Intervention Theory) } \\
\text { can effectively improve the psychological } \\
\text { capital of USWL }\end{array}$ & $3 / * * *$ \\
\hline $\begin{array}{l}\text { Littman-Ovadia } 2013[\mathrm{x}] \\
\text { Looking forward to } \\
\text { tomorrow: The buffering } \\
\text { effect of a daily optimism } \\
\text { intervention }\end{array}$ & Israel & $\begin{array}{l}\text { Randomized controlled trial; } \\
\text { Students were assigned to a } \\
\text { seven-day optimism } \\
\text { intervention group }(\mathrm{N}=36) \\
\text { and a control group }(\mathrm{N}=41) \\
\text { and were assessed } \\
\text { pre-intervention, } \\
\text { immediately } \\
\text { post-intervention and one } \\
\text { month post-intervention. }\end{array}$ & $\begin{array}{l}\text { Qualitative } \\
\text { measures of }\end{array}$ & & $3 / * * *$ \\
\hline $\begin{array}{l}\text { Ortega-Maldonado } 2018[\mathrm{x}] \\
\text { Psychological capital and } \\
\text { performance among } \\
\text { undergraduate students: the } \\
\text { role of meaning-focused } \\
\text { coping and satisfaction }\end{array}$ & Spain & $\begin{array}{l}\text { Prospective cohort; College } \\
\text { students ( } \mathrm{n}=682 \text { ) completed } \\
\text { an academic well-being } \\
\text { survey at two points and } \\
\text { performance data was } \\
\text { collected five months later }\end{array}$ & Quantitative survey & $\begin{array}{l}\text { PsyCap was directly related to performance, } \\
\text { and indirectly related to performance } \\
\text { through meaning-focus coping and } \\
\text { satisfaction; PsyCap was directly associated } \\
\text { with satisfaction, highlighting the } \\
\text { importance of this psychological construct } \\
\text { in academic settings }\end{array}$ & $3 / * * *$ \\
\hline $\begin{array}{l}\text { Ouweneel } 2013 \text { (x) } \\
\text { Do-it-yourself: An online } \\
\text { positive psychology } \\
\text { intervention to } \\
\text { promote positive emotions, } \\
\text { self-efficacy, and } \\
\text { engagement at work }\end{array}$ & Netherlands & $\begin{array}{l}\text { Experimental design, } \\
\text { pretest-posttest } \\
\text { questionnaires, }(\mathrm{n}=878)\end{array}$ & $\begin{array}{l}\text { Surveys (Personal, } \\
\text { self-reported) }\end{array}$ & $\begin{array}{l}\text { Our self-enhancement intervention had no } \\
\text { significant short-term effect on work } \\
\text { engagement, at least, not at first glance. } \\
\text { Employees who already are engaged and } \\
\text { experiencing positive emotions and } \\
\text { self-efficacy at work are likely to be } \\
\text { motivated in enhancing their own well-being } \\
\text { even } \\
\text { further }\end{array}$ & 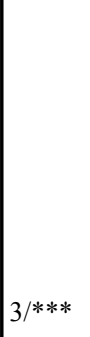 \\
\hline $\begin{array}{l}\text { Williams } 2016 \text { (June 15) } \\
\text { Exploring Selective } \\
\text { Exposure and Confirmation } \\
\text { Bias as Processes } \\
\text { Underlying Employee Work } \\
\text { Happiness: An Intervention } \\
\text { Study }\end{array}$ & Australia & $\begin{array}{l}\text { Quasi-experimental study } \\
\text { design, 3-day intervention } \\
\text { (6h), questionnaire } \\
\text { pre-intervention, } \\
\text { immediately after } \\
\text { intervention, 8-week } \\
\text { post-intervention, on school } \\
\text { staff }(\mathrm{n}=69)\end{array}$ & $\begin{array}{l}\text { Online surveys, } \\
\text { questionnaires }\end{array}$ & $\begin{array}{l}\text { results showed that PsyCap significantly } \\
\text { increased from time } 1 \text { (pre-intervention) to } \\
\text { time } 2 \text { [post-intervention; } \mathrm{t}(88)=3.41, \mathrm{p}= \\
0.001] . \text { This provides preliminary support } \\
\text { that the intervention triggers change in } \\
\text { participants }\end{array}$ & $3 / * * *$ \\
\hline $\begin{array}{l}\text { Akkermans } 2015 \text { [x] It's All } \\
\text { About CareerSKILLS: } \\
\text { Effectiveness of a Career } \\
\text { Development Intervention } \\
\text { for Young Employees }\end{array}$ & Netherlands & $\begin{array}{l}\text { Quasi-randomized control } \\
\text { trial; Students from a dutch } \\
\text { educational institution } \\
(\mathrm{n}=173) \text { and participants } \\
\text { from a reemployment } \\
\text { program in a Dutch } \\
\text { multinational ( } \mathrm{n}=113) \\
\text { underwent a four-day } \\
\text { CareerSKILLS intervention; } \\
\text { Asses pre-intervention, } \\
\text { post-intervention and two }\end{array}$ & $\begin{array}{l}\text { Quantitative } \\
\text { measures of career } \\
\text { competencies, } \\
\text { work-related } \\
\text { self-efficacy, } \\
\text { resilience against } \\
\text { setbacks, } \\
\text { career-related } \\
\text { behaviours and } \\
\text { perceived } \\
\text { employability, }\end{array}$ & $\begin{array}{l}\text { Intervention resulted in increase in all } 6 \\
\text { career competencies, work-related } \\
\text { self-efficacy and resilience against setbacks } \\
\text { and in career-related behaviours and } \\
\text { perceived employability compared with the } \\
\text { control group. }\end{array}$ & $3 / * * * *$ \\
\hline
\end{tabular}




\begin{tabular}{|c|c|c|c|c|c|}
\hline & & \begin{tabular}{|l|} 
weeks after. $69.4 \%$ of \\
participants in Sample 1 were \\
male, mean age of 19 years; \\
$51.3 \%$ were female in \\
Sample 2, mean age of 33 \\
years. $(\mathrm{N}=278)$
\end{tabular} & $\begin{array}{l}\text { work engagement, } \\
\text { and satisfaction } \\
\text { with the } \\
\text { intervention. }\end{array}$ & & \\
\hline $\begin{array}{l}\text { Costantini } 2017(\mathrm{x}) \text { Work } \\
\text { engagement and } \\
\text { psychological capital in the } \\
\text { Italian public administration: } \\
\text { A new resource-based } \\
\text { intervention programme }\end{array}$ & Italy & $\begin{array}{l}\text { Quasi-experimental design: } \\
\text { pre-test, intervention (3-day), } \\
\text { post-test, of white-collar and } \\
\text { blue-collar employees } \\
\text { working in an Italian public } \\
\text { health administration. }(\mathrm{n}=54)\end{array}$ & Questionnaires & $\begin{array}{l}\text { Psychological capital plays an active and } \\
\text { dynamic role in boosting employees' levels } \\
\text { of work engagement. }\end{array}$ & $3 / * * * *$ \\
\hline $\begin{array}{l}\text { Da } 2020 \text { (Dec 23) } \\
\text { Effectiveness of } \\
\text { Psychological Capital } \\
\text { Intervention and Its } \\
\text { Influence on Work-Related } \\
\text { Attitudes: Daily Online } \\
\text { Self-Learning Method and } \\
\text { Randomized Controlled } \\
\text { Trial Design }\end{array}$ & China & $\begin{array}{l}\text { Randomized control trial }(1 \\
\text { week) on full-time } \\
\text { employees in mainland China } \\
\text { (age } 20-60 \text { years), follow-up } \\
\text { test }(1 \text { week later) }(n=104)\end{array}$ & $\begin{array}{l}\text { Questionnaires } \\
\text { (Self-report), } \\
\text { surveys }\end{array}$ & $\begin{array}{l}\text { A daily online self-learning PsyCap } \\
\text { intervention is effective at improving } \\
\text { PsyCap levels and has positive influences, } \\
\text { increasing job satisfaction and decreasing } \\
\text { turnover intention. }\end{array}$ & $3 / * * * *$ \\
\hline $\begin{array}{l}\text { Li } 2020 \text { (May 11) Effects of } \\
\text { Mindfulness Training on } \\
\text { Psychological Capital, } \\
\text { Depression, and } \\
\text { Procrastination of the Youth } \\
\text { Demographic }\end{array}$ & China & $\begin{array}{l}\text { Experimental design: } \\
\text { intervention }(1.5-2 \mathrm{~h} \text { per } \\
\text { session, } 2-3 \text { times weekly for } \\
9 \text { weeks }) \text { on youth in China } \\
(\mathrm{n}=240)\end{array}$ & $\begin{array}{l}\text { Questionnaire } \\
\text { survey, } \\
\text { telephone/online } \\
\text { video interviews }\end{array}$ & $\begin{array}{l}\text { Mindfulness training can improve } \\
\text { psychological capital of the youth } \\
\text { demographic effectively and relieve their } \\
\text { depression, thereby improving their } \\
\text { procrastination. }\end{array}$ & $3 / * * * *$ \\
\hline $\begin{array}{l}\text { Luthans } 2018 \text { (Oct } 1) \\
\text { Refining Grit in Academic } \\
\text { Performance: The } \\
\text { Mediational Role of } \\
\text { Psychological Capital }\end{array}$ & USA & $\begin{array}{l}\text { Correlation study design, } \\
\text { with business students } \\
\text { surveyed in March 2017, and } \\
\text { corresponding GPA collected } \\
\text { in May } 2018(\mathrm{n}=176)\end{array}$ & $\begin{array}{l}\text { 24-item PsyCap } \\
\text { Questionnaire } \\
\text { (adapted for } \\
\text { academic domain), } \\
\text { 8-item short grit } \\
\text { scale, GPA }\end{array}$ & $\begin{array}{l}\text { Academic PsyCap consisting of the } \\
\text { psychological resources of hope, efficacy, } \\
\text { resiliency, and optimism seem to help drive } \\
\text { gritty students toward more successful } \\
\text { academic performance. }\end{array}$ & $3 / * * * *$ \\
\hline $\begin{array}{l}\text { Meevissen } 2011[\mathrm{x}] \text { Become } \\
\text { more optimistic by } \\
\text { imagining a best possible } \\
\text { self: Effects } \\
\text { of a two week intervention }\end{array}$ & Netherlands & $\begin{array}{l}\text { Randomized-controlled trial; } \\
\text { Participants were assigned to } \\
\text { a 5-minute imagery exercise } \\
\text { (daily for } 2 \text { weeks) } \\
\text { intervention group or a } \\
\text { control group and assessed at } \\
\text { pre- and post-intervention; } \\
\text { Participants were students of } \\
\text { Maastricht University } \\
(\mathrm{n}=54)\end{array}$ & Questionnaires & $\begin{array}{l}\text { Imagining a best possible self imagery } \\
\text { intervention resulted in an increase in } \\
\text { optimism levels in intervention groups } \\
\text { compared to controls. }\end{array}$ & 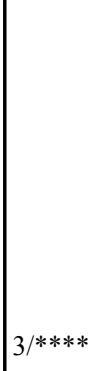 \\
\hline $\begin{array}{l}\text { Meyers } 2015(\mathrm{x}) \text { Enhancing } \\
\text { psychological capital and } \\
\text { personal growth initiative: } \\
\text { Working on strengths or } \\
\text { deficiencies }\end{array}$ & $x^{2}$ & $\begin{array}{l}\text { Longitudinal experiment: } 1 \\
\text { week pre intervention, post } \\
\text { intervention immediately, } \\
\text { 1-month follow up, } \\
\text { additional 3-month follow up } \\
\text { on graduate students (master } \\
\text { students in social sciences) } \\
(\mathrm{n}=105)\end{array}$ & Questionnaires & $\begin{array}{l}\text { Strengths intervention increased the } \\
\text { students' PGI in the short but not in the long } \\
\text { term; relationship between the strengths } \\
\text { intervention and PGI } \\
\text { was mediated by hope as one component of } \\
\text { PsyCap. }\end{array}$ & $3 / * * * *$ \\
\hline $\begin{array}{l}\text { Motanpotra } 2019(\mathrm{x}) \\
\text { Development of an } \\
\text { Intervention Module of } \\
\text { Psychological Capital to } \\
\text { Enhance the Workplace }\end{array}$ & India & $\begin{array}{l}\text { Experimental design: survey } \\
\text { prior to intervention, } \\
\text { intervention, survey after } \\
\text { intervention }(>=2 \text { months } \\
\text { after intervention) on }\end{array}$ & Surveys & $\begin{array}{l}\text { The results show that all the dimensions of } \\
\text { OCB underwent a significant increase } \\
\text { immediately after the intervention. } \\
\text { Counterproductive workplace behaviors are } \\
\text { reduced by the presence of high PsyCap in } \\
\text { employees. }\end{array}$ & $3 / * * * *$ \\
\hline
\end{tabular}




\begin{tabular}{|c|c|c|c|c|c|}
\hline $\begin{array}{l}\text { Behaviors and Emotions of } \\
\text { Employees }\end{array}$ & & $\begin{array}{l}\text { private-sector employees } \\
(\mathrm{n}=535)\end{array}$ & & & \\
\hline $\begin{array}{l}\text { Wingerden } 2014[\mathrm{x}] \text { A test } \\
\text { of a job demands-resources } \\
\text { intervention }\end{array}$ & Netherlands & $\begin{array}{l}\text { Quasi-experimental study; } \\
\text { Participants were assigned to } \\
\text { a job demands-resources } \\
\text { intervention consisting of } 3 \\
\text { sessions over } 5 \text { weeks or a } \\
\text { control group and were } \\
\text { assessed } 2 \text { weeks pre- and } 1 \\
\text { week post-intervention; } \\
\text { Participants were healthcare } \\
\text { professionals treating } \\
\text { patients with hearing } \\
\text { impairment. }(\mathrm{N}=67)\end{array}$ & $\begin{array}{l}\text { Quantitative } \\
\text { Questionnaires }\end{array}$ & $\begin{array}{l}\text { The intervention group reported higher } \\
\text { PsyCap, job crafting, work engagement and } \\
\text { in-role performance compared to the control } \\
\text { group. PsyCap was significantly related to } \\
\text { work engagement and work engagement } \\
\text { affected in-role performance }\end{array}$ & $3 / * * * *$ \\
\hline $\begin{array}{l}\text { Meyers } 2016 \text { (x) Effects of a } \\
\text { Strengths Intervention on } \\
\text { General } \\
\text { and Work-Related } \\
\text { Well-Being: The Mediating } \\
\text { Role } \\
\text { of Positive Affect }\end{array}$ & Netherlands & $\begin{array}{l}\text { Experimental design: pretest } \\
\text { ( } 2 \text { weeks before } \\
\text { intervention)-posttest, } \\
\text { 1-month follow-up } \\
\text { questionnaire on Dutch } \\
\text { working people ( } \mathrm{n}=116)\end{array}$ & $\begin{array}{l}\text { Questionnaires } \\
\text { (Self-report), } \\
\text { surveys }\end{array}$ & $\begin{array}{l}\text { Participating in a strengths intervention } \\
\text { creates short-term increases in employee } \\
\text { positive affect and short- and long-term } \\
\text { increases in psychological capital. }\end{array}$ & $3 / * * * * *$ \\
\hline $\begin{array}{l}\text { Fontes } 2020[\mathrm{x}] \text { An } \\
\text { Experimental Field Study on } \\
\text { the Effects of Coaching: The } \\
\text { Mediating Role of } \\
\text { Psychological Capital }\end{array}$ & France & $\begin{array}{l}\text { Randomized controlled } \\
\text { study; Participants were } \\
\text { assigned to a 4-month-long } \\
\text { oaching intervention or a } \\
\text { wait-list control group and } \\
\text { assessed pre, post- and } \\
\text { 4-months post-intervention; } \\
\text { Participants were employees } \\
\text { in a marketing company. } \\
(\mathrm{N}=56)\end{array}$ & $\begin{array}{l}\text { Quantitative } \\
\text { Questionnaires }\end{array}$ & $\begin{array}{l}\text { Coaching is related to improvements in } \\
\text { PsyCap, job attitudes and one dimension of } \\
\text { job performance. PsyCap played a mediating } \\
\text { role for job attitudes. The effects on PsyCap } \\
\text { and job attitudes lasted over time. }\end{array}$ & $4 / * *$ \\
\hline $\begin{array}{l}\text { Harty } 2015[\mathrm{x}] \text { Group } \\
\text { intervention: A way to } \\
\text { improve working teams' } \\
\text { positive psychological } \\
\text { capital. }\end{array}$ & Sweden & $\begin{array}{l}\text { Experimental design: } \\
10 \text {-week group intervention, } \\
\text { assessment pre and post } \\
\text { intervention, 6-month } \\
\text { follow-up }(\mathrm{n}=8)\end{array}$ & $\begin{array}{l}\text { Semi-structured } \\
\text { interview }\end{array}$ & $\begin{array}{l}\text { Group intervention: A way to improve } \\
\text { working teams' positive psychological } \\
\text { capital. }\end{array}$ & $4 / * *$ \\
\hline $\begin{array}{l}\text { Lin } 2016(\mathrm{x}) \text { Fostering } \\
\text { change-oriented behaviors: } \\
\text { A broaden-and-build model }\end{array}$ & Taiwan & $\begin{array}{l}\text { Quantitative descriptive } \\
\text { design: 3-wave data } \\
\text { collection, 2-source design } \\
\text { (6-week) with professional } \\
\text { workers }(\mathrm{n}=257)\end{array}$ & Questionnaires & $\begin{array}{l}\text { psychological capital mediates the } \\
\text { relationship between positive affect and } \\
\text { employees' creative performance and taking } \\
\text { charge }\end{array}$ & $4 / * *$ \\
\hline $\begin{array}{l}\text { Avey } 2009[\mathrm{x}] \text { Psychological } \\
\text { capital: A positive resource } \\
\text { for combating employee } \\
\text { stress and turnover }\end{array}$ & United States & $\begin{array}{l}\text { Prospective cohort; Adults } \\
\text { from a varietY of jobs were } \\
\text { assessed for Psycap and } \\
\text { 2-weeks later pertaining to } \\
\text { stress symptoms, intentions } \\
\text { to quit and job search } \\
\text { behaviours. }(\mathrm{n}=416)\end{array}$ & Quantitative results & $\begin{array}{l}\text { PsyCap was positively related to stress } \\
\text { symptoms and significantly and negatively } \\
\text { related to employee intentions to quit. }\end{array}$ & $4 / * * *$ \\
\hline $\begin{array}{l}\text { Bonner } 2016[x] \text { A survey of } \\
\text { work engagement and } \\
\text { psychological capital levels }\end{array}$ & UK & $\begin{array}{l}\text { Cross-sectional study; } \\
\text { Participants were registered } \\
\text { nurses }(n=137)\end{array}$ & $\begin{array}{l}\text { Quantitative } \\
\text { Questionnaires }\end{array}$ & $\begin{array}{l}\text { High levels of work engagement were } \\
\text { significantly correlated with high levels of } \\
\text { PsyCap. Nurses working at band } 5 \text { level had } \\
\text { lower PsyCap scores compared to band } 6 \\
\text { and band } 7 \text { level nurses. }\end{array}$ & $4 / * * *$ \\
\hline
\end{tabular}




\begin{tabular}{|c|c|c|c|c|c|}
\hline $\begin{array}{l}\text { Burns } 2016 \text { (Mar 30) } \\
\text { Examining the relationship } \\
\text { of organizational insiders' } \\
\text { psychological capital with } \\
\text { information security threat } \\
\text { and coping appraisals }\end{array}$ & USA & $\begin{array}{l}\text { Quantitative descriptive } \\
\text { design on insider employees } \\
\text { in public and private sectors } \\
(\mathrm{n}=377)\end{array}$ & $\begin{array}{l}\text { Surveys (including } \\
\text { self-report) }\end{array}$ & $\begin{array}{l}\text { results of this study support the symbiotic } \\
\text { relationship between positive psychological } \\
\text { factors and organizational security } \\
\text { outcomes. }\end{array}$ & $4 / * * *$ \\
\hline $\begin{array}{l}\text { Cesaro } 2016[\mathrm{x}] \\
\text { Psychological capital as a } \\
\text { mediator between team } \\
\text { cohesion and productivity }\end{array}$ & United States & $\begin{array}{l}\text { Cross-sectional study; } \\
\text { Performance Management } \\
\text { Teams (PMTs) in a U.S. } \\
\text { defense organization } \\
\text { completed surveys }(\mathrm{N}=45)\end{array}$ & $\begin{array}{l}\text { Quantiataive } \\
\text { surveys of PsyCap, } \\
\text { team cohesion and } \\
\text { team productivity. }\end{array}$ & $\begin{array}{l}\text { Team cohesion did not predict team } \\
\text { productivity and psychological capital did } \\
\text { not mediate team cohesion and productivity. } \\
\text { Cohesion and psychological capital have a } \\
\text { significant positive effect on supervisor } \\
\text { performance ratings but the effect is } \\
\text { diminished when viewing the objective } \\
\text { measure of productivity }\end{array}$ & $4 / * * *$ \\
\hline $\begin{array}{l}\text { Chen } 2019 \text { (July 12) How } \\
\text { Leaders' Psychological } \\
\text { Capital Influence Their } \\
\text { Followers' Psychological } \\
\text { Capital: Social Exchange or } \\
\text { Emotional Contagion }\end{array}$ & China & $\begin{array}{l}\text { Quantitative descriptive } \\
\text { design, with participants } \\
\text { working in financial } \\
\text { enterprises (leaders and } \\
\text { followers) (n= } 32 \text { teams ( } 321 \\
\text { followers)) }\end{array}$ & $\begin{array}{l}\text { Self-rating } \\
\text { questionnaires }\end{array}$ & $\begin{array}{l}\text { the quality of the relationship played a more } \\
\text { important role in the process of } \\
\text { psychological capital's interaction. }\end{array}$ & $4 / * * *$ \\
\hline $\begin{array}{l}\text { Gonçalves } 2017 \text { (x) The } \\
\text { relation between leader's } \\
\text { humility and team creativity: } \\
\text { The mediating effect of } \\
\text { psychological safety and } \\
\text { psychological capital }\end{array}$ & Portugal & $\begin{array}{l}\text { Quantitative descriptive } \\
\text { design, comparing leaders' } \\
\text { self-perception of humility } \\
\text { with how subordinates view } \\
\text { their leaders, from SMEs } \\
\text { (Small Medium Enterprises) } \\
(\mathrm{n}=73)\end{array}$ & $\begin{array}{l}\text { Questionnaires } \\
\text { (self-assessment, } \\
\text { wisdom to see } \\
\text { others' efforts, } \\
\text { openness to new } \\
\text { ideas) }\end{array}$ & $\begin{array}{l}\text { Humility of the leaders explains the } \\
\text { psychological safety, which affects the } \\
\text { psychological capital of the team, which } \\
\text { explains the creativity of the team and the } \\
\text { leader's humility explains the creativity of } \\
\text { the team through the mediator effect of } \\
\text { psychological safety and of psychological } \\
\text { capital. }\end{array}$ & $4 / * * *$ \\
\hline $\begin{array}{l}\text { Hassan } 2019 \text { (Nov 26) The } \\
\text { Role of Psychological } \\
\text { Capital in Language } \\
\text { Learners' Willingness to } \\
\text { Communicate, Motivation, } \\
\text { and Achievement }\end{array}$ & Iran & $\begin{array}{l}\text { Quantitative descriptive } \\
\text { design, 15-min questionnaire } \\
\text { with undergraduate students } \\
\text { majoring in English language } \\
\text { and literature }(\mathrm{n}=317)\end{array}$ & $\begin{array}{l}\text { Questionnaire } \\
\text { (Compound } \\
\text { PsyCap Scale in } \\
\text { Persian) }\end{array}$ & $\begin{array}{l}\text { Learners' PsyCap was a positive significant } \\
\text { predictor of learners' second/foreign } \\
\text { language (L2) willingness to communicate, } \\
\text { L2 motivational self system, and L2 } \\
\text { achievement }\end{array}$ & $4 / * * *$ \\
\hline $\begin{array}{l}\text { Verleysen } 2014[\mathrm{x}] \text { Building } \\
\text { Psychological } \\
\text { Capital With Appreciative } \\
\text { Inquiry: Investigating } \\
\text { the Mediating Role of } \\
\text { Basic Psychological Need } \\
\text { Satisfaction }\end{array}$ & Netherlands & $\begin{array}{l}\text { Repeated measure study, } 2 \\
\text { full days a month; } \\
\text { participants worked in social } \\
\text { profit organizations } \\
\text { Participants with AI } \\
\text { experience }(\mathrm{n}=81) \text { and a } \\
\text { group without AI experience } \\
(\mathrm{n}=132)\end{array}$ & $\begin{array}{l}\text { Online } \\
\text { questionnaire }\end{array}$ & $\begin{array}{l}\text { Satisfying the need for competence mediates } \\
\text { the relationship between participating in AI } \\
\text { and the PsyCap dimensions; Participating in } \\
\text { AI } \\
\text { satisfies the three BPN }\end{array}$ & 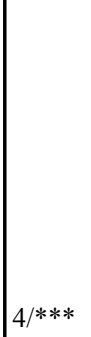 \\
\hline $\begin{array}{l}\text { Agarwal } 2017 \text { (Mar 13) } \\
\text { High-performance work } \\
\text { systems and creativity } \\
\text { implementation: the role of } \\
\text { psychological capital and } \\
\text { psychological safety }\end{array}$ & $\begin{array}{l}\text { Pay wall/ } \\
\text { Limited } \\
\text { access }\end{array}$ & $\begin{array}{l}\text { Cross-sectional study } \\
(\mathrm{n}=505)\end{array}$ & Surveys & $\begin{array}{l}\text { people management practices can encourage } \\
\text { creativity implementation in the workplace. }\end{array}$ & $4 / * * * *$ \\
\hline $\begin{array}{l}\text { Carter } 2019 \text { (x) The positive } \\
\text { psychology of mentoring: A } \\
\text { longitudinal analysis of } \\
\text { psychological capital } \\
\text { development and } \\
\text { performance in a formal } \\
\text { mentoring program }\end{array}$ & USA & $\begin{array}{l}\text { 4-year longitudinal study, } \\
\text { controlling pre-program } \\
\text { performance and over } \\
\text { multiple time periods, with } \\
\text { formal organizations }(n=115)\end{array}$ & Quantitative & $\begin{array}{l}\text { results support the effectiveness of the } \\
\text { mentoring program in developing PsyCap } \\
\text { and enhancing performance 1 year later in } \\
\text { three cohorts of protégés }\end{array}$ & $4 / * * * *$ \\
\hline
\end{tabular}




\begin{tabular}{|c|c|c|c|c|c|}
\hline $\begin{array}{l}\text { Luthans } 2016[\mathrm{x}] \text { A positive } \\
\text { approach to management } \\
\text { education: The relationship } \\
\text { between academic PsyCap } \\
\text { and student engagement }\end{array}$ & USA & $\begin{array}{l}\text { Cross-sectional study; } \\
\text { Participants were assessed } \\
\text { for PsyCap levels and levels } \\
\text { of engagement in educational } \\
\text { activities; Participants were } \\
\text { undergraduate business } \\
\text { students from } 2 \text { Midwestern } \\
\text { universities. }(\mathrm{N}=323)\end{array}$ & $\begin{array}{l}\text { Quantitative } \\
\text { surveys }\end{array}$ & $\begin{array}{l}\text { PsyCap significantly predicted student } \\
\text { engagement and was associated with a } \\
\text { significant increase in variance explained in } \\
\text { student engagement. }\end{array}$ & $4 / * * * *$ \\
\hline $\begin{array}{l}\text { Reichard } 2013(\mathrm{x}) \\
\text { Development of } \\
\text { Cross-Cultural } \\
\text { Psychological Capital and } \\
\text { Its Relationship } \\
\text { With Cultural Intelligence } \\
\text { and } \\
\text { Ethnocentrism }\end{array}$ & USA & $\begin{array}{l}\text { Quasi-experimental design, } \\
\text { pretest-posttest measured } \\
\text { before and after intervention } \\
\text { (2-hour session) on USA and } \\
\text { South African participants } \\
\mathrm{N}=122 \text { (USA), N=71 (SA, } \\
\text { university staff) }\end{array}$ & 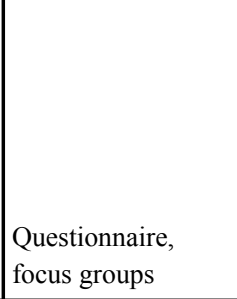 & $\begin{array}{l}\text { Training effects were maintained for more } \\
\text { than } 1 \text { month for both PsyCap and CQ. } \\
\text { Stability in PsyCap, } \\
\mathrm{t}(53)=-1.24, \mathrm{~ns}, \mathrm{CQ}, \mathrm{t}(50)=-0.55, \mathrm{~ns} \text {, and } \\
\text { ethnocentrism, } \mathrm{t}(51)=1.23, \mathrm{~ns} \text {, from Time } 2 \\
\text { (posttraining assessment) to Time } 3 \text { ( } 1 \text { to } 2 \\
\text { months following training) }\end{array}$ & $4 / * * * *$ \\
\hline $\begin{array}{l}\text { Zuberbuhler } 2020 \text { (Jan 30) } \\
\text { Coaching-Based Leadership } \\
\text { Intervention Program: A } \\
\text { Controlled Trial Study }\end{array}$ & Spain & $\begin{array}{l}\text { Mixed methods design: five } \\
180 \text {-min weekly intervention, } \\
\text { immediate feedback pre and } \\
\text { post intervention of workers } \\
\text { in the automotive sector }(n= \\
42)\end{array}$ & $\begin{array}{l}\text { Online research } \\
\text { questionnaires }\end{array}$ & $\begin{array}{l}\text { the intervention program was successful in } \\
\text { increasing the participants' coaching-based } \\
\text { leadership skills, PsyCap, work engagement, } \\
\text { and in- and extra-role performance. }\end{array}$ & $5 / * *$ \\
\hline $\begin{array}{l}\text { Georgiou } 2018 \text { (Nov 28) } \\
\text { The influence and } \\
\text { development of } \\
\text { psychological capital } \\
\text { in the job search context }\end{array}$ & Greece & $\begin{array}{l}\text { Mixed study design, survey } \\
\text { (study 1) and } \\
\text { quasi-experimental study, } \\
\text { pre-intervention assessment } \\
\text { (study } 2 \text { ) of unemployed job } \\
\text { seekers } \\
\text { n=447 (study 1) n=361 } \\
\text { (study 2) }\end{array}$ & $\begin{array}{l}\text { Questionnaires } \\
\text { (self-measure } \\
\text { psycap and } \\
\text { job-search } \\
\text { behaviour) }\end{array}$ & $\begin{array}{l}\text { PsyCap might help individuals persist in job } \\
\text { seeking, resulting in more interviews, offers, } \\
\text { and employment. PsyCap can be developed } \\
\text { among job seekers through the PsyCap } \\
\text { intervention model. }\end{array}$ & $5 / * * *$ \\
\hline $\begin{array}{l}\text { Sharp } 2017 \text { (Dec) Career } \\
\text { crescendo An experimental } \\
\text { analysis of a 6-week } \\
\text { work-site intervention to } \\
\text { determine the developmental } \\
\text { capacity of psychological } \\
\text { capital }\end{array}$ & USA & $\begin{array}{l}\text { Mixed-method design: } \\
\text { quantitative analysis } \\
\text { followed by a follow-up } \\
\text { study, 6-week intervention } \\
\text { training of full-time } \\
\text { employees }(\mathrm{n}=49)\end{array}$ & $\begin{array}{l}\text { Surveys (pre-test } \\
\text { post-test), in-depth } \\
\text { interviews }\end{array}$ & $\begin{array}{l}\text { The findings from the present study make a } \\
\text { much stronger case for the developmental } \\
\text { capacity of PsyCap through worksite } \\
\text { interventions. }\end{array}$ & (1) \\
\hline $\begin{array}{l}\text { Burns } 2013 \text { (Nov) The } \\
\text { impact of organizational } \\
\text { insiders' psychological } \\
\text { capital on information } \\
\text { security }\end{array}$ & USA & $\begin{array}{l}\text { Mixed methods design, } \\
\text { multi-dimensional research } \\
\text { model tested by survey } \\
\text { research methodology, pilot } \\
\text { study, with organizational } \\
\text { insiders }(\mathrm{n}=414)\end{array}$ & $\begin{array}{l}\text { Online surveys and } \\
\text { questionnaires }\end{array}$ & $\begin{array}{l}\text { Insiders' PsyCap was positively related to } \\
\text { PMBs as well, indicating that PsyCap does } \\
\text { provide a necessary resource for taking on } \\
\text { the paradoxical roles required by modem } \\
\text { information security. }\end{array}$ & $5 / * * * *$ \\
\hline $\begin{array}{l}\text { Devall-Martin } 2017 \text { (School } \\
\text { administrators' insight and } \\
\text { self-reflection: An } \\
\text { exploration of the influence } \\
\text { of expressive writing and the } \\
\text { Luminaspark(c) inventory } \\
\text { on self-awareness) }\end{array}$ & USA & $\begin{array}{l}\text { Mixed method design: pre- } \\
\text { and 24-hour post-self } \\
\text { assessment, with teachers in } \\
\text { Ontario (USA) }(\mathrm{N}=10)\end{array}$ & $\begin{array}{l}\text { Questionnaire, } \\
\text { Psychological } \\
\text { Well-being } \\
\text { Inventory }\end{array}$ & $\begin{array}{l}\text { While the magnitude of participants' overall } \\
\text { PsyCap pre- and post intervention was } \\
\text { positively reported with the LuminaSpark } \subset \\
\text { group, psychological well-being, and } \\
\text { self-reflection and insight showed decreases } \\
\text { that may be due to too short a time frame to } \\
\text { see potential change. }\end{array}$ & $5 / * * * *$ \\
\hline $\begin{array}{l}\text { Diedrich } 2015(\mathrm{x}) \\
\text { Psychological capital: An } \\
\text { intervention method for } \\
\text { developing organization } \\
\text { leadership in a mental health } \\
\text { center }\end{array}$ & USA & $\begin{array}{l}\text { Mixed method design, pre } \\
\text { and post-intervention } \\
\text { assessments, with leaders in a } \\
\text { mental health care system } \\
(\mathrm{n}=30)\end{array}$ & $\begin{array}{l}\text { Quantitative } \\
\text { survey, qualitative } \\
\text { interviews }\end{array}$ & $\begin{array}{l}\text { Developing PsyCap in leadership supports } \\
\text { achieving strategic goals among the stresses } \\
\text { created by the Affordable Care Act }\end{array}$ & $5 / * * * *$ \\
\hline
\end{tabular}


